\title{
Az új orális antikoagulánsokkal történő kezelés laboratóriumi vonatkozásai
}

\author{
Bereczky Zsuzsanna dr. ${ }^{1}$. Oláh Zsolt dr. ${ }^{2}$ \\ Ajzner Éva dr. ${ }^{4}$ - Kappelmayer János dr. ${ }^{3}$ \\ Debreceni Egyetem, Általános Orvostudományi Kar, ${ }^{1}$ Klinikai Laboratóriumi Kutató Tanszék, \\ ${ }^{2}$ Aneszteziológiai és Intenzív Terápiás Tanszék, ${ }^{3}$ Laboratóriumi Medicina Intézet, Debrecen \\ ${ }_{4}^{4}$ Jósa András Oktató Kórház, Központi Laboratórium, Nyíregyháza
}

\begin{abstract}
Az évtizedek óta várt új orális antikoagulánsok (NOAC) egyre bővülő körben alkalmazott gyógyszerekké váltak a terápiában, hiszen az orális antikoagulánsként korábban egyedüliként alkalmazott kumarinszármazékokhoz képest számos klinikai indikációban a kumarinokkal azonos vagy annál jobb klinikai hatékonyságot mutatnak. Ennek következtében a direkt trombininhibitor dabigatran, majd a direkt X-es alvadási faktort gátló szerek (rivaroxaban, apixaban, edoxaban) az elmúlt években a napi terápiás gyakorlat részévé váltak. Elterjedésüket nem kis részben segítette azon ajánlás, hogy nem igényelnek laboratóriumi monitorizálást, ami mind a beteg, mind a kezelőorvos számára rendkívül nagy előnyt jelent. Az elmúlt évek tapasztalatai azonban bebizonyították, hogy a 'one size fits all' szemlélet erősen szimplifikált a NOAC-terápia során, és számos olyan eset van, amikor ezen gyógyszerek koncentrációjának monitorizálása elkerülhetetlen vagy erôsen ajánlott. Ez az összefoglaló tanulmány a NOAC-kezelés laboratóriumi vonzatait tárgyalja, kiemelten a hemosztázis alap- és speciális tesztjeire való hatásukat, valamint a korrekt NOACkoncentráció meghatározására szolgáló laboratóriumi módszereket.
\end{abstract}

Orv Hetil. 2017; 158(49): 1930-1945.

Kulcsszavak: dabigatran, rivaroxaban, apixaban, edoxaban, laboratóriumi monitorizálás

\section{Laboratory aspects of novel oral anticoagulant treatment}

The introduction of novel oral anticoagulants (NOAC) have long been expected drugs and they quickly became used widespread as their clinical effectiveness was as good as, or even better than the previously used only oral anticoagulant drug, the coumarins. Thus, the direct thrombin inhibitor dabigatran and the activated factor $\mathrm{X}$ inhibitors (rivaroxaban, apixaban, edoxaban) have become the part of daily therapeutic practice. Their permeation was facilitated by the guideline which suggested that no laboratory monitoring was required during NOAC treatment and this was very convenient for both patients and doctors. The clinical experience obtained in the past years, however have proved that the 'one size fits all' view is oversimplified and there are numerous situations when the determination NOAC levels is unavoidable or highly recommended. This review discusses the laboratory aspects of NOAC treatment, primarily summarizing their effect on the screening tests and special assays of hemostasis and we also describe the correct methods to determine their plasma concentrations.

Keywords: dabigatran, rivaroxaban, apixaban, edoxaban, laboratory monitoring

Bereczky Zs, Oláh Zs, Ajzner É, Kappelmayer J. [Laboratory aspects of novel oral anticoagulant treatment]. Orv Hetil. 2017; 158(49): 1930-1945.

(Beérkezett: 2017. szeptember 7.; elfogadva: 2017. október 10.)

Az Orvosi Hetilap 160. évében a Szerkesztőség felkérésére készült tanulmány. 


\section{Rövidítések}

ACCP $=$ (American College of Chest Physicians) Amerikai Mellkasorvosok Kollégiuma; APTI = aktivált parciális tromboplasztin idő; $\mathrm{AT}=$ antitrombin; $\mathrm{BCRP}=($ breast cancer resistance protein) emlőrákrezisztencia-protein; $\mathrm{CYP}=$ citokróm $\mathrm{P}$; DTI $=$ direkt trombininhibitor; DOAC $=$ direct oral anticoagu lant; EMA = (European Medicines Agency) Európai Gyógyszerfelügyelet; FDA = (US Food and Drug Administration) az Amerikai Egyesült Államok Élelmiszer-biztonsági és Gyógyszerészeti Hivatala; GFR = (glomerular filtration rate) glomeruláris filtrációs ráta; $\mathrm{INR}=$ (international normalised ratio) nemzetközi normalizált ráta; LA = lupus anticoagulans; LC-MS $/$ MS = (liquid chromatography-tandem mass spectrometry) folyadékkromatográfia-tandem tömegspektrometria; $\mathrm{LMWH}=$ (low molecular weight heparin $)$ alacsony molekula tömegú heparin; NOAC $=$ (novel oral anticoagulant $)$ új orális antikoaguláns; $\mathrm{P}$-gp $=\mathrm{P}$-glikoprotein; $\mathrm{PI}=$ protrombinidő; $\mathrm{PF}=$ pitvarfibrilláció $; \mathrm{POCT}=$ (point-of-care testing ) point-ofcare tesztek; ROTEM = rotációs tromboelasztográf; TI = trombinidő; UFH = (unfractionated heparin) nem frakcionált heparin; VKA = (vitamin $\mathrm{K}$ antagonist) $\mathrm{K}$-vitamin-antagonista; $\mathrm{VTE}=$ vénás thromboembolia

Az antikoaguláns kezelés történetében az első, specifikus alvadásgátlóként használt hatóanyag a heparin volt, amelyet 1918-ban fedezett fel McLean [1, 2]. Hatását az antitrombinhoz (AT) - mint kofaktorhoz - kötődve fejti ki, megsokszorozva az AT szerinproteázokat gátló hatását, elsődlegesen az aktív II-es és X-es (FIIa és FXa) alvadási faktor gátlását. A heparin humán klinikai kipróbálására az 1920-as évek végén került sor, majd a nagy tisztaságú heparin előállításához szükséges módszerek kifejlesztését követôen, az 1930-as évek második felében kezdték el egyre nagyobb számú betegen alkalmazni. Ezt követően 1941-ben Link munkacsoportjának sikerült a dikumarolt kristályos állapotban izolálni [3], majd elkezdődött annak humán kipróbálása is. Az elkövetkezó években rohamosan nőtt a dikumarollal kezelt betegek száma és a gyógyszerrel kapcsolatos ismeretanyag, amely végül az első, szájon át szedhető alvadásgátló készítménynek bizonyult. A szer alkalmazása mérföldkő volt az antikoaguláns terápia területén, amely a későbbiekben elvezetett a szintetikus kumarinok elóállításához és klinikai alkalmazásához. Évtizedeken át kizárólag a K-vitamin-antagonistaként (VKA) múködő kumarinszármazékok álltak rendelkezésre per os szedhető alvadásgátló készítményként. A heparinnal, az 1980-as évek második felétől pedig egyre inkább a kis molekulatömegú heparinnal (LMWH) átfedésben, laboratóriumi kontroll mellett beállított kumarinkezelés a hosszú távú alvadásgátló terápia évtizedeken át uralkodó, standard és igen hatékony módszerévé vált. Ezen kezelésnek vannak azonban árnyoldalai is: a heparinok és származékai csak parenteralisan alkalmazhatók, míg a per os kumarinkezelést a szúk terápiás ablak, a számos gyógyszerrel és étkezéssel kapcsolatos interakciók, illetve a metabolizmusban részt vevő enzimrendszerek polimorfizmusai teszik kényelmetlenné és időnként kiszámíthatatlanná. A fentiek mi- att a kumarinkezelés rendszeres és szoros laboratóriumi kontrollja szükséges a megfelelő alvadásgátló hatás biztosítása és a vérzéses szövődmények elkerülése érdekében.

A 2000-es évek elejére a tudatos gyógyszertervezés eredményeként kifejlesztették az első, szájon át szedhető, specifikus trombin- és FXa-inhibitorokat, amelyeket közös néven NOAC-ként (kezdetben novel oral anticoagulant, napjainkban non-vitamin $\mathrm{K}$ oral anticoagulant angol kifejezés rövidítéseként) vagy esetleg DOACként (direct oral anticoagulant) emlegetünk. A nagy betegszámú, randomizált vizsgálatok kedvező eredményei alapján 2008-ban engedélyezték ezen készítmények első képviselőinek a rutin-betegellátásban, megfelelő indikációkkal történő alkalmazását is. Jelen összefoglalóban a NOAC-készítmények klinikai alkalmazásának bizonyos aspektusait és kiemelten a NOAC-kezelés laboratóriumi vonatkozásait tárgyaljuk.

\section{A NOAC-készítmények általános jellemzése}

\section{Farmakokinetika, farmakodinámia}

A NOAC-készítmények direkt antikoagulánsként müködnek, tehát alvadásgátló hatásuk kifejtéséhez nincs szükségük kofaktorra: kompetitív módon, reverzibilis antagonistaként, specifikusan kötődnek az adott alvadási faktor aktív centrumához, gátolva annak múködését. Az indirekt módon ható antikoagulánsokkal szemben a thrombusban található, kötött alvadási faktorok gátlására is képesek a szabadon keringők mellett [4].

Támadáspont szerint két csoportba sorolható be a jelenleg Magyarországon elérhető négy NOAC-készítmény: a dabigatran etexilat (Pradaxa) a direkt trombininhibitor csoport egyetlen képviselője, míg az apixaban (Eliquis), rivaroxaban (Xarelto) és edoxaban (Lixiana) a direkt FXa-inhibitorok csoportjába tartoznak. Fontosabb farmakokinetikai jellemzőiket az 1. táblázatban foglaljuk össze. A készítményeket per os alkalmazzuk, a bélből gyorsan felszívódnak. A vérben a csúcskoncentrációt hamar, egy-négy órán belül elérik, ezért a VKA-kkal szemben már a terápia kezdetén sem indokolt heparinnal vagy bármely egyéb antikoagulánssal történő együttes, átfedő adása. Általánosságban mindegyik készítményről elmondható, hogy kiszámítható farmakokinetikával és farmakodinámiával rendelkezik, ezért jó máj- és vesefunkció esetén fix napi dózisban adható, laboratóriumi kontroll pedig a mindennapi használat során nem szükséges. Relatíve rövid féléletidővel (általában 10-17 óra) jellemezhetők, amely az esetleges NOAC-hoz köthetó komplikációk jelentkezése esetén előnyös, hiszen a gyógyszer kihagyását követően vérszintjük gyorsan csökken, másrészt kiemeli a megfelelő compliance fontosságát a beteg részéről a thromboemboliás szövődmények megelőzése érdekében.

Az FXa-inhibitorok farmakokinetikáját a májban - elsősorban a CYP3A4 enzimrendszeren - történő metabo- 
1. táblázat |A NOAC-készítmények farmakokinetikai jellemzői

\begin{tabular}{|c|c|c|c|c|c|}
\hline & Dabigatran & Apixaban & Edoxaban & Rivaroxaban & Betrixaban \\
\hline Biohasznosulás & $6-7 \%$ & $50 \%$ & $62 \%$ & $80-100 \%$ & $34 \%$ \\
\hline Csúcskoncentráció elérése (per os) & 2 óra & 3-4 óra & 1-2 óra & 2-4 óra & 3-4 óra \\
\hline Féléletidő & 12-17 óra & 8-12 óra & 10-14 óra & $9-13$ óra & 19-27 óra \\
\hline Vese (elimináció) & $80 \%$ & $27 \%$ & $50 \%$ & $33 \%$ & $<7 \%$ \\
\hline Fehérjekötés & $35 \%$ & $87 \%$ & $55 \%$ & $92-95 \%$ & $60 \%$ \\
\hline Megoszlási térfogat & $50-70 \mathrm{~L}$ & $21 \mathrm{~L}$ & $>300 \mathrm{~L}$ & $\begin{array}{l}50 \mathrm{~L} \\
0,62 \mathrm{~L} / \mathrm{kg}\end{array}$ & $32 \mathrm{~L} / \mathrm{kg}$ \\
\hline
\end{tabular}

lizmus és a vesén keresztül történő elimináció, illetve ezek gyógyszerenként eltérő aránya határozza meg. Ezzel szemben a dabigatran metabolizmusában a CYP450 enzimrendszer nem vesz részt, nagyrészt a vesén keresztül távozik. Minden NOAC farmakokinetikájában fontos szerepet tölt be a P-glikoprotein (P-gp) efflux transzporter, amely elsősorban a NOAC-készítmények felszívódását képes befolyásolni a bélhámsejtekbe már abszorbeálódott gyógyszer béllumenbe történő visszapumpálása révén. A P-gp a vesében zajló aktív exkrécióban is szerepet játszhat egyes NOAC-készítmények esetében, hozzájárulva az adott gyógyszer eliminációjához. A P-gp fokozott aktivitása tehát - részben a felszívódó gyógyszer mennyiségének csökkentése, részben a vesén keresztül kiválasztódó gyógyszer mennyiségének növelése révén - csökkenti a gyógyszer plazmakoncentrációját, míg gátlása épp ellenkezőleg, emeli azt. A NOAC-készítmények metabolizmusának ismeretében érthetővé válik a viszonylag csekély számú gyógyszer-interakció mechanizmusa is. Az FXa-inhibitoroknál elsősorban a P-gp és a CYP3A4 enzimrendszer, dabigatran alkalmazásánál csak a P-gp aktivitását befolyásoló gyógyszerek esetében kell interakcióval számolni. A fontosabb CYP3A4 és P-gpinhibitorokat, valamint induktorokat a 2. táblázatban soroljuk fel.

Az egyes készítmények eliminációjában különbözó mértékben játszik szerepet a vese: legnagyobb mértékben, mintegy $80 \%$-ban a dabigatran, majd rendre csökkenő mértékben, 50\%, 33\% és 27\%-ban az edoxaban, rivaroxaban és apixaban ürül a vesén át. Emiatt tehát a glomeruláris filtrációs ráta (GFR) meghatározásának döntő jelentősége van a terápia alkalmazásakor. Általánosságban elmondható, hogy $30 \mathrm{ml} /$ perc alatti GFR-érték minden NOAC esetében relatív vagy abszolút ellenjavallatot képez és komoly megfontolást igényel.

Fázis III, randomizált, nagy betegszámmal bíró klinikai vizsgálatok alapján megállapítható, hogy a NOACkészítmények az elfogadott indikációkban legalább olyan hatékonynak bizonyultak, mint a sokáig standard terápiaként elfogadott, és egyébként is hatásosnak tartható hagyományos LMWH/VKA kezelés, míg egyes vizsgálatok az adott NOAC-kezelés szuperioritását is igazolták. Ezen megállapítások a csípő- és térdprotézisműtétek utáni vénás thromboembolia (VTE) megelőzését illetően is igazak. A NOAC-készítmények ortopédiai VTE-prevencióban vizsgált adagjai egyenértékünek, rivaroxaban és apixaban esetében még hatékonyabbnak is bizonyultak a Magyarországon leginkább alkalmazott, szubkután adagolt, napi $1 \times 40 \mathrm{mg}$ enoxaparinkezeléssel szemben, míg vérzéses szövődmények tekintetében szignifikáns különbség egyik esetben sem mutatkozott [5-11].

A fent említett, nagy betegszámú, randomizált vizsgálatok bizonyították ezen készítmények biztonságosságát is. Több mint 100000 beteg adatait felölelő, magas evidenciaszinttel bíró fázis III vizsgálatok metaanalízise alapján a NOAC-kezelés mellett szignifikánsan kevesebb volt mind a major, mind a fatális, az intracranialis, a klinikailag releváns nem major és az összes vérzés aránya a K-vitamin-antagonista készítményt szedő betegek csoportjával összehasonlítva [12]. Bár egyes klinikai tanulmányokban a gastrointestinalis $(\mathrm{GI})$ vérzések aránya ma-

2. táblázat $\mid$ CYP3A4 és P-glikoprotein-inhibitorok és induktorok (kiemelve a P-gp és CYP3A4 egyaránt erős inhibitorai és induktorai)

\begin{tabular}{|c|c|}
\hline CYP3A4 erős gátlói & P-gp erős gátlói \\
\hline $\begin{array}{l}\text { Azol tipusú antimikotikumok } \\
\text { (ketokonazol, itrakonazol, } \\
\text { vorikonazol, pozakonazol) } \\
\text { HIV-proteáz-gátlók } \\
\text { Klaritromicin }\end{array}$ & $\begin{array}{l}\text { Azol típusú antimikotikumok } \\
\text { (ketokonazol, itrakonazol, } \\
\text { vorikonazol, pozakonazol) } \\
\text { HIV-proteáz-gátlók } \\
\text { Ciklosporin } \\
\text { Dronedaron } \\
\text { Takrolimusz }\end{array}$ \\
\hline $\begin{array}{l}\text { CYP3A4 gyenge, közepesen erős } \\
\text { gátlói }\end{array}$ & P-gp gyenge, közepesen erős gátlói \\
\hline $\begin{array}{l}\text { Diltiazem } \\
\text { Eritromicin }\end{array}$ & $\begin{array}{l}\text { Amiodaron } \\
\text { Kinidin } \\
\text { Verapamil } \\
\text { Tikagrelor } \\
\text { Diltiazem } \\
\text { Naproxen } \\
\text { Makrolid antibiotikumok } \\
\text { (eritromicin, } \\
\text { klaritromicin, azitromicin) }\end{array}$ \\
\hline \multicolumn{2}{|l|}{ CYP3A4 és P-gp erós induktorai } \\
\hline $\begin{array}{l}\text { Rifampicin } \\
\text { Fenitoin } \\
\text { Karbamazepin } \\
\text { Fenobarbitál } \\
\text { Orbáncfü }\end{array}$ & \\
\hline
\end{tabular}


gasabbnak bizonyult a nagy dózisú dabigatrant $(2 \times 150$ $\mathrm{mg})$, edoxabant $(1 \times 60 \mathrm{mg})$ vagy rivaroxabant szedő betegek esetében a VKA-csoporthoz képest [13], ezen metaanalízis szerint összességében nem mérhető szignifikáns különbség a két betegcsoport között e tekintetben [12]. Az elmúlt években számos metaanalízis vizsgált különböző NOAC-készítmények eltérő adagjaival kezelt, különféle szempontok szerint megválasztott betegcsoportokat, amelyek időnként nem egybecsengő, ellentmondásos eredményeket adtak a betegcsoportok eltérő rizikófaktorai és a vizsgálat szempontjai szerint. Általánosságban azonban elmondható, hogy a NOACkészítményekkel kezelt betegek körében a vérzéses szÖvődmények aránya kevesebb vagy megegyezik a VKA-val kezelt betegcsoporttal, míg egyértelműnek látszik mind a randomizált, kontrollált, mind a posztmarketing-vizsgálatok szerint, hogy a NOAC-kezeléssel szignifikánsan kevesebb intracranialis és fatális vérzés társul $[14,15]$. Ismét fel kell hívni azonban a figyelmet arra, hogy bizonyos NOAC-okkal kezelt alcsoportokban a GI-vérzés veszélye fokozott lehet. Amint látható, a NOAC-kezelés megfelelő indikáció mellett, a relatív és abszolút ellenjavallatok betartásával biztonságosnak tartható, a terápia leggyakoribb szövődménye azonban továbbra is a vérzés maradt. Ilyen esetekben, illetve sürgős invazív beavatkozásoknál szükséges lehet a NOAC hatásának felfüggesztése. Ezért különösen örvendetes, hogy 2015 óta elérhetô az első specifikus antidotum idarucizumab (Praxbind) néven, amely a dabigatran hatását képes gyorsan és jelentôs mértékben felfüggeszteni $[16,17]$. FXa-inhibitorok esetében ígéretes vizsgálatok zajlanak az andexanet-alfa és a ciraparantag alkalmazásával, azonban ezek még nincsenek kereskedelmi forgalomban [16], így jelenleg sürgős invazív beavatkozásoknál vagy a terápiához társuló vérzés esetén protrombinkomplex-koncentrátum, esetleg rekombináns FVIIa adható [17].

\section{Klinikai alkalmazás, indikációk}

A NOAC-készítmények jelenleg a következő elfogadott és törzskönyvezett indikációs körrel rendelkeznek felnőtt betegek esetében:

1. Stroke és szisztémás embolisatio megelözése nem valvularis eredetû pitvarfibrillációban (PF), akiknél legalább egy rizikófaktor fennállása igazolható a következők közül: pangásos szívelégtelenség, hypertonia, életkor $>75$ év, diabetes mellitus, korábbi stroke, tranziens ischaemiás attak vagy egyéb szisztémás embolisatio.

2. Mélyvéna-thrombosis és/vagy pulmonalis embolia kezelése és a visszatérô vénás thromboembolia megelőzése.

3. Vénás thromboembolia (VTE) megelözése elektív csípő- vagy térdprotézismútéten átesett betegeknél. (Az edoxaban még nem adható ebben a betegcsoportban.)
A NOAC-készítmények a fenti indikációs körben egyre nagyobb szerepet kapnak a mindennapi klinikai gyakorlatban, alkalmazásuk fokozatosan növekszik a standard terápiával szemben. Az American College of Chest Physicians (ACCP) legújabb, 2016-os ajánlásában a VTE kezelése során a NOAC-készítményeket előnyben részesíti a VKA-kezeléssel szemben, amennyiben a beteg nem szenved malignus alapbetegségben. Daganatos betegeknél a jelenleg elsőként választandó kezelési mód továbbra is az LMWH, bár NOAC-készítménnyel is zajlik tanulmány malignus betegséghez társuló VTE kapcsán [18].

Az Európai Kardiológiai Társaság a NOAC-készítményeket ajánlja az első helyen pitvarfibrillációhoz társuló stroke és szisztémás embolisatio prevenciója céljára nonvalvularis PF esetén [19], akut tüdőembolia kezelésekor pedig a standard terápia megfelelő alternatívájaként tekint a NOAC-készítményekre [20].

Magyarországon az Országos Egészségbiztosítási Pénztár, illetve utódja, a Nemzeti Egészségbiztosítási Alapkezelő a NOAC-készítmények alkalmazását csak akkor támogatja elsőként választott terápiaként, ha a VKAkezelés ellenjavallt. Támogatott továbbá a NOAC-kezelés, ha a VKA-kezelés bizonyítottan súlyos vagy kellemetlen mellékhatásokkal jár (például nőknél kopaszodás).

Zajló és részben lezárult nagy nemzetközi tanulmányok eredményei alapján várhatóan artériás thrombosisok kezelése során is szerepet kaphatnak majd a NOACkészítmények a közeli jövőben.

A NOAC-készítmények adagolásával kapcsolatos ajánlásokat a hivatalos alkalmazási előírásokra támaszkodva a 3. táblázatban foglaljuk össze az eltérő indikációs területeken.

\section{Kontraindikációk}

Mechanikus múbillentyúvel élő betegeknél alkalmazott dabigatran a RE-ALIGN vizsgálatban nem váltotta be a hozzáfüzött reményeket; mind a vérzés, mind a thromboemboliás szövődmények aránya megemelkedett a warfarinnal kezelt kontrollcsoporthoz képest, így a NOAC-készítmények alkalmazása ellenjavallt ezen betegek esetében [21], ahogy szoptatás és terhesség mellett sem adhatóak. Terhesség során véletlenszerú NOAC-expozíció azonban már előfordult, illetve előfordulhat; a jelenleg rendelkezésre álló kis betegszámú vizsgálat alapján a terhesség megszakítása csak emiatt nem indokolt. Húsz, szüléssel végződött terhességbőll három esetben tapasztaltak szövődményt: két, rivaroxabant szedő betegnél veseüreg-rendszeri tágulat, arcdiszmorfizmus és a terhesség befejezését szükségessé tevő praeeclampsia, illetve egy, dabigatrant szedő betegnél kis születési súly jelentett problémát [22].

NOAC-terápia természetesen nem alkalmazható aktív vérzés fennálltakor, illetve a potenciálisan életet veszélyeztető és major vérzéses szövődmények magas rizikója 
esetén (például májelégtelenség), amikor a kezeléshez társuló vérzés veszélye meghaladja a készítmény által nyújtotta előnyöket. Ahogyan azt korábban már részleteztük, a NOAC-gyógyszerek eliminálása részben - bár az egyes készítmények esetében eltérô arányban - a vesén keresztül történik, így súlyos veseelégtelenségben alkalmazásuk szintén kontraindikált, illetve vesefunkcióhoz illesztett dózismódosítás lehet szükséges. NOACkészítmény nem kombinálható egyéb antikoaguláns hatású készítménnyel (VKA, heparin, LMWH, fondaparinux stb.). Kivételt a NOAC-ról VKA-ra történő átállás rövid időszaka jelenthet, a terápiás INR-érték eléréséig.

A kiszámítható farmakokinetika és farmakodinámia következtében - az alkalmazásra vonatkozó előírások betartása mellett - a NOAC-kezelés nem igényel laboratóriumi monitorozást. Sürgős invazív beavatkozás előtt, a perioperatív időszakban, illetve vérzéses szövődmény jelentkezése esetén mégis nagyon hasznos és szükséges a NOAC-koncentráció legalább hozzávetőleges, lehetôség szerint azonban minél pontosabb ismerete a további teendők elbírálása céljából.

\section{Az egyes NOAC-készítmények részletes jellemzése}

\section{Dabigatran (Pradaxa $75 \mathrm{mg}, 110 \mathrm{mg}, 150 \mathrm{mg}$ )}

A dabigatran volt az első törzskönyvezett NOACkészítmény, amelyet az Európai Gyógyszerfelügyelet (European Medicines Agency - EMA) 2008-ban, az Amerikai Egyesült Államokban az Élelmiszer-biztonsági és Gyógyszerészeti Hivatal (US Food and Drug Administration - FDA) pedig 2010-ben fogadott be Pradaxa néven. Szintetikus, kis molekulasúlyú peptidomimetikum, amely az FII aktív centrumához univalens módon kötődve a szabad és fibrinkötött trombin múködését egyaránt képes gátolni [23], megakadályozva ezáltal a fibrinogén-fibrin átalakulást, az FV, FVIII és FIX trombin általi aktivációját, mérsékelve így a további trombingenerációt. Mindezek mellett gátolja a trombin thrombocytaaktiváló hatását is [24]. A dabigatran etexilat egy prodrug, amely felszívódását követően, észteráz által katalizált hidrolízis során a májban alakul át aktív dabigatranná. Magyarországon az ortopédiai thromboprofilaxis céljára $75 \mathrm{mg}$-os, vénás thromboembolia és pitvarfibrilláció kezelésére 110 és 150 mg-os kiszerelésben érhető el. A kapszula $0,8 \mathrm{~mm}$-es pelleteket tartalmaz, amelyben a tartarátsav magot veszi körbe a dabigatran. A tartarátsav a felszívódáshoz teremti meg a kedvező savas mikrokörnyezetet, illetve a gyomor $\mathrm{pH}$-változásaitól függetlenné teszi a készítmény felszívódását, másrészt felelőssé tették a relatíve gyakori dyspepsiás panaszokért.

Étkezéstől függetlenül szedhető, biohasznosulása per os alkalmazást követően 6-7\%. A kapszulák nem megbonthatóak, kapszulahéj nélkül ugyanis a dabigatran biohasznosulása akár 75\%-kal is megemelkedhet. A plazmacsúcskoncentrációt a bevétel után két órán belül eléri. Ezt követően a rapid disztribúciónak köszönhetően - a bevételhez képest négy-hat órán belül - szintje a maximális plazmakoncentráció 30\%-a alá csökken a vérben, majd egy relatíve elhúzódó eliminációs fázis következik. A CYP enzimrendszeren keresztül nem metabolizálódik: $80 \%$-a a vesén keresztül ürül változatlanul, $20 \%$-a glükuronidokká konjugálódik, amelyek az alapvegyülettel megegyező aktivitást mutatnak [25]. A készítmény terminális féléletideje 12-17 óra, és a csekély mértékú fehérjekötésnek köszönhetően viszonylag jól dializálható.

Az idarucizumab (Praxbind) egy monoklonális antitest, amelyhez a dabigatran irreverzibilisen, 350-szer nagyobb affinitással kötődik, mint a trombinhoz, majd az 1:1 arányú antitest/dabigatran komplex a vesén keresztül ürül ki a szervezetből. Az idarucizumab gyorsan és hatékonyan képes felfüggeszteni a dabigatran hatását vérzés esetén, vagy nagy vérzésveszéllyel járó invazív beavatkozás előtt $[16,26]$.

\section{Rivaroxaban (Xarelto $10 \mathrm{mg}, 15 \mathrm{mg}, 20 \mathrm{mg}$ )}

A rivaroxaban a direkt FXa-inhibitorok első képviselőjeként vonult be a klinikai gyakorlatba. Magyarországon ortopédiai thromboprofilaxisra $10 \mathrm{mg}-\mathrm{Os}$, VTE és PF esetén 15 és 20 mg-os kiszerelésben érhető el. A gyógyszert étkezés közben javasolt bevenni, így biohasznosulása 80-100\%, míg éhgyomor esetén csak 66\%. A Xarelto tabletta összetörhető, nasogastricus szondán át ilyen formában adagolható a farmakokinetikai jellemzők érdemi változása nélkül. A plazmában 2-4 óra alatt éri el a csúcskoncentrációt, felezési ideje 5-13 óra. Plazmafehérjékhez, elsősorban albuminhoz nagy arányban (92-95\%) kötődik, nem dializálható. A rivaroxaban egyharmada változatlanul ürül a vizelettel nagyrészt aktív szekréció útján a P-gp-és a BCRP- (emlőrákrezisztencia-protein) transzporter fehérjék révén, kisebb részben glomeruláris filtráció által. A rivaroxaban további kétharmada a májban, elsősorban a CYP3A4 enzimrendszeren keresztül, illetve nem CYP450-függő módon, hidrolízis révén metabolizálódik, majd az így keletkezett inaktív metabolitok egyenlő arányban ürülnek a vesén és a hepatobiliaris rendszeren keresztül [27]. A farmakokinetika nemtől és testtömegtől függetlennek tekinthető. Időskorban a csökkent clearance miatt felezési ideje némileg növekedhet, de a beteg kora önmagában nem indokol dózismódosítást. Amennyiben a GFR értéke $15 \mathrm{ml} /$ perc alá csökken, a rivaroxaban alkalmazása abszolút ellenjavallt, 15-30 ml/perc közötti GFR-értéknél alkalmazása komoly megfontolást igényel, a hivatalos alkalmazási előirat szerint $15-50 \mathrm{ml}$ /perc közötti GFR-értéknél a dózis csökkentése javasolható.

\section{Apixaban (Eliquis $\mathbf{2 , 5} \mathbf{~ m g}, 5 \mathbf{~ m g}$ )}

Az apixaban a gyógyszer bevételét követően $50 \%$-os biohasznosulás mellett három órán belül éri el a plazmacsúcskoncentrációt, eliminációs féléletideje 12 óra. Farmakokinetikai tulajdonságait az étkezés érdemben nem befolyásolja, étkezés közben vagy attól függetlenül is bevehető. Porrá törve, nasogastricus szondán át is alkal- 
mazható. A beadott mennyiség 27\%-a - a nálunk elérhető NOAC-készítmények között a legkisebb arányban változatlanul ürül a vesén át, nagyobb része azonban a széklettel távozik metabolitok formájában, illetve egy része változatlanul. A májban részben nem CYP rendszeren keresztül demetiláció és hidroxiláció történik, illetve dominálóan a CYP3A4 enzim útján metabolizálódik [28]. Szubsztrátja a P-gp- és BCRP-transzport fehérjéknek is.

Bár a NOAC-készítmények között viszonylag kis arányban választódik ki a vesén keresztül - részletes vizsgálatok hiányában -, amennyiben a GFR értéke $15 \mathrm{ml} /$ perc alá csökken, alkalmazása ellenjavallt, $15-29 \mathrm{ml} /$ perc GFR-értéknél pedig csökkentett dózis $(2 \times 2,5 \mathrm{mg})$ használatát javasolják pitvarfibrillációban stroke-prevenció céljára. Adagolását a testsúly és az életkor is befolyásolja (3. táblázat).

\section{Edoxaban (Lixiana $30 \mathrm{mg}, 60 \mathrm{mg}$ )}

Az edoxaban csúcskoncentrációját l-2 óra alatt éri el a vérben, biohasznosulása $62 \%$, féléletideje 10-14 óra. Étkezés nem befolyásolja a készítmény farmakokinetikai jellemzőit, így bevétele étkezéshez nem kötött, attól függetlenül alkalmazható. A vesén keresztül az 50\%-a, a fennmaradó hányad hidrolízis, konjugáció vagy a CYP3A4 révén metabolizálódik [29]. Az edoxaban adása ellenjavallt GFR $<15 \mathrm{ml} /$ perc esetén. A javasolt dózis 15-50 ml/perc GFR-értéknél l × $30 \mathrm{mg}, 50-80 \mathrm{ml} /$ perc esetén $1 \times 60 \mathrm{mg}$. Az edoxaban az efflux transzporter P-gp szubsztrátja.

\section{Betrixaban (Bevyxxa $80 \mathrm{mg}, 40 \mathrm{mg}$ )}

Az FDA 2017 júniusában fogadta el az FXa-inhibitorcsoport legújabb képviselőjét, a NOAC-gyógyszercsoportban új indikációs körrel: a betrixaban (Bevyxxa) felnőtt, heveny betegség miatt hospitalizált, nem sebészeti betegek esetében alkalmazható kiterjesztett VTE-profilaxis céljára emelkedett VTE-rizikó esetén (http://www. bevyxxa.com/docs/Bevyxxa-Full-Prescribing-Information.pdf). A szájon át adandó betrixaban gyorsan felszívódik, csúcskoncentrációját a plazmában 3-4 órán belül éri el. Biohasznosulása 34\%, amelynek mértékét az étkezés jelentősen csökkentheti, ennek ellenére az alkalmazási előirat szerint étkezés közben kell bevenni. A betrixaban közel 14\%-a hidrolízis révén metabolizálódik, és csak elenyésző mennyiségben $(<1 \%)$ a CYP450 enzimrendszeren keresztül, csökkentve ezáltal a gyógyszer-interakciók lehetôségét. A nem metabolizálódó betrixaban nagy része a széklettel ürül, míg kis mennyiségben $(<7 \%)$ a vesén keresztül. Féléletideje a többi NOAC-készítménynyel összehasonlítva hosszú [30].

A kezdő dózis az első napon $1 \times 160 \mathrm{mg}$, majd napi $80 \mathrm{mg} / \mathrm{nap}$ az ajánlott adag 35-42 napon át. A P-gp szubsztrátja, ezért P-gp-inhibitor szedése mellett, illetve GFR $15-30 \mathrm{ml} /$ perc tartományban a fenti adagokat felezni kell, $15 \mathrm{ml}$ /perc alatti GFR-értéknél pedig, adatok hiányában, alkalmazása nem javasolt.
3. táblázat | NOAC-készítmények javasolt adagolása

\begin{tabular}{|c|c|c|c|}
\hline & Pitvarfibrilláció & VTE & Ortopédia \\
\hline \multirow[t]{2}{*}{ Dabigatran } & \multicolumn{2}{|l|}{$2 \times 150 \mathrm{mg} / \mathrm{nap}$} & $\begin{array}{l}\text { 1. nap } 1 \times 110 \\
\mathrm{mg}, \text { majd } 1 \times \\
220 \mathrm{mg} / \text { nap }\end{array}$ \\
\hline & \multicolumn{2}{|c|}{$\begin{array}{l}2 \times 110 \mathrm{mg} / \mathrm{nap}:>80 \text { életév } \\
\text { vagy verapamil egyidejű szedése }\end{array}$} & $\begin{array}{l}\text { 1. nap } 1 \times 75 \\
\text { mg, majd } 1 \times \\
150 \mathrm{mg} / \text { nap: } \\
\text { GFR 30-50 } \\
\mathrm{ml} / \text { perc vagy } \\
>75 \text { év vagy } \\
\text { verapamil, } \\
\text { amiodaron, } \\
\text { kinidin } \\
\text { egyidejü } \\
\text { szedése }\end{array}$ \\
\hline \multirow[t]{2}{*}{ Rivaroxaban } & $1 \times 20 \mathrm{mg} / \mathrm{nap}$ & \multirow{2}{*}{$\begin{array}{l}1-21 . \text { nap } 2 \times \\
15 \mathrm{mg}, \text { majd } \\
1 \times 20 \mathrm{mg} / \text { nap }\end{array}$} & \multirow[t]{2}{*}{$1 \times 10 \mathrm{mg} / \mathrm{nap}$} \\
\hline & $\begin{array}{l}1 \times 15 \mathrm{mg} / \\
\text { nap: GFR } \\
15-50 \mathrm{ml} / \text { perc }\end{array}$ & & \\
\hline \multirow[t]{2}{*}{ Apixaban } & $2 \times 5 \mathrm{mg} / \mathrm{nap}$ & \multirow{2}{*}{$\begin{array}{l}7 \text { napig } 2 \times 10 \\
\text { mg, majd } 6 \\
\text { hónapig } 2 \times 5 \\
\mathrm{mg}, \text { majd } 2 \times \\
2,5 \mathrm{mg} / \text { nap }\end{array}$} & \multirow{2}{*}{$\begin{array}{l}2 \times 2,5 \mathrm{mg} / \\
\text { nap }\end{array}$} \\
\hline & $\begin{array}{l}2 \times 2,5 \mathrm{mg} / \\
\text { nap: }>80 \text { év, } \\
<60 \mathrm{~kg} \text { vagy } \\
\text { kreatinin } \\
>133 \mu \mathrm{mol} / \mathrm{L} \\
\text { (mindkettő } \\
\text { teljesülése } \\
\text { esetén) }\end{array}$ & & \\
\hline \multirow[t]{2}{*}{ Edoxaban } & \multicolumn{2}{|l|}{$1 \times 60 \mathrm{mg} / \mathrm{nap}$} & \\
\hline & \multicolumn{2}{|c|}{$\begin{array}{l}1 \times 30 \mathrm{mg} / \text { nap: GFR } 15-50 \\
\mathrm{ml} / \text { perc, }<60 \mathrm{~kg} \text {, ciklosporin, } \\
\text { dronedaron, eritromicin, } \\
\text { ketokonazol egyidejü szedése } \\
\text { (legalább egy a fentiek közül) }\end{array}$} & \\
\hline
\end{tabular}

A táblázat nem tartalmazza az adott gyógyszerekkel kapcsolatos ellenjavallatokat, amelyek eleve kizárják a készítmény alkalmazásának lehetőségét.

A pontos dózis megállapítása mindig egyéni elbírálást igényel, mérlegelve a vérzés rizikóját is.

\section{Az új típusú orális antikoagulánsok laboratóriumi monitorozása}

A NOAC-készítmények, amint azt ebben a közleményben is kifejtjük, ma már egyre bővülő indikációban alkalmazva, igen széles körben elterjedtek a hazai antikoaguláns kezelési gyakorlatban. Ezen készítmények elterjedése a laboratóriumok számára is kihívást jelent, hiszen a korai általános vélekedéssel ellentétben ma már nyilvánvaló, hogy a laboratóriumi kontrolltól nem lehet teljesen eltekinteni, sôt bizonyos esetekben kifejezetten veszélyes ezen készítmények laboratóriumi ellenőrzés nélkül történő adása. A hagyományos koagulációs szűrő" tesztek (protrombinidő, APTI, trombinidő) nem alkalmasak a NOAC-készítmények szintjének/hatásának pontos meghatározására, így nincsen a K-vitamin-anta- 
gonistáknál jól bevált INR-hez hasonló egyszerű, gyors véralvadási teszt, amellyel a készítmények „in vivo” hatásának mértéke megítélhető volna.

\section{A NOAC-monitorozás indikációi}

A NOAC-terápia megválasztásakor (az indikáció tisztázása mellett) feltétlenül szükséges a beteg vesefunkciójának feltérképezése [31-35]. A májfunkció vizsgálata szintén indokolt, májelégtelenségben ugyanis fokozott a major vérzéses szövődmények veszélye (lásd fent).

Megfelelő vesefunkciójú beteg esetén, a mai álláspont szerint, rendszeres gyógyszerszint-monitorozásra nincs szükség. A különböző klinikai tanulmányok fix dózisban adott NOAC-terápia mellett hatékonynak, noninferiornak bizonyultak a K-vitamin-antagonistákkal, illetve heparinnal szemben, ezért kezdetben a laboratóriumi kontrollt teljesen szükségtelennek tartották. Ez a kezdeti határozott álláspont azonban az évek alatt „real-life betegeken" gyújtött tapasztalatok hatására változott [3639]. A legfontosabb kérdések egy NOAC-terápián lévő betegnél ugyanis a következőek:

- Megfelelően gátolja-e a gyógyszer a thromboembolia kialakulását?

- Vérzés fellépése esetén állhat-e annak hátterében NOAC-túladagolás (mérgezés)?

- Szedi-e a beteg az elóírt NOAC-készítményt, vagyis milyen a compliance?

- NOAC-kezelés mellett elszenvedett stroke esetén részesülhet-e a beteg thrombolysisben, mekkora ilyenkor a vérzésveszély?

- Trauma vagy akut mútét esetén várható-e súlyos vérzés NOAC-terápián lévő betegnél?

E kérdések, bizonytalanságok megválaszolásában a laboratóriumi mérések nagy segítséget nyújthatnak [40, 41]. A „one dose fits all” (azonos dózis mindenkinek megfelelő) hozzáállás nem feltétlenül tükrözi a valóságot, ugyanis a NOAC-terápiára állított betegek életkora, testsúlya, vese- és májfunkciója jelentős különbségeket mutathat, valamint ismertek gyógyszer-interakciók is (P-glikoprotein-induktorok, inhibitorok, CYP3A4/5), amelyek befolyásolják e gyógyszerek szintjét. A „real-life betegeknél”, fóleg az időseknél, gyakorta egyéb társbetegségek is fennállnak, amelyek a gyógyszer-interakciók esélyét növelik. Az utóbbi időben megjelentek esetismertetések, ahol a vérzések hátterében egyértelmúen a NOAC-túladagolás állt; az igen magas gyógyszerszintek közvetlen összefüggésbe hozhatóak a vérzéses eseményekkel [42]. Kimutatták továbbá, hogy a NOAC-szintek mind a völgy-, mind a csúcskoncentrációt figyelembe véve jelentős, vesefunkciótól független különbségeket mutatnak a betegeknél [43]. Ennek jelentősége a thromboprofilaxis hatékonysága szempontjából ma még nem tisztázott, azonban a kezdeti irodalmi adatok alapján elképzelhető, hogy - főleg a hosszú távú antikoagulálás esetén - a klinikai kimenetelt befolyásolja a NOAC-szint. A NOAC-terápián lévő betegek invazív beavatkozások alkalmával vérzésveszélynek vannak kitéve és a mai álláspont az, hogy 48 órával a beavatkozás előtt elegendő a gyógyszer elhagyása. Van adat azonban arra is, hogy ez az időablak nem feltétlenül elegendő a $30 \mu \mathrm{g} / \mathrm{L}$ határérték alá történő gyógyszerszintcsökkenéshez, ahol már elvileg elhanyagolható a vérzésveszély, ezért mütétek előtt is lehet haszna a NOAC-szint-meghatározásnak. Végül, a túladagolás miatt kialakuló vérzések során alkalmazott antagonista készítmények, a dabigatrannál az idarucizumab (Praxbind) és az anti-FXa-készítményeknél az andexanet-alfa (AndexXa) esetén azok hatékonyságának, azaz a gyógyszerek eliminálásának követésére is hasznos a gyógyszerszint-meghatározás.

Mindezen megfontolások alapján ma az alábbi esetekben javasolják a NOAC-szint meghatározását [44, 45]:

- váratlan vérzés (túladagolás, mérgezés?) vagy throm-

bosis mejelenése a kezelés alatt,

- extrém testsúly esetén,

- akut ischaemiás stroke esetén thrombolysis előtt,

- sebészi (sürgősségi invazív) beavatkozás előtt,

- akut (progresszív) veseelégtelenség kialakulása esetén,

- akut (progresszív) májelégtelenség kialakulása esetén,

- compliance megítélése érdekében,

- gyógyszer-interakció feltételezésekor (például P-gpinduktorok vagy -inhibitorok).

Újabban felmerült az individualizált dózis megállapításának koncepciója is, ami a fenti megfontolások alapján logikusnak tûnik, azonban ma még erre vonatkozóan nincsenek ajánlások.

Ahhoz, hogy a NOAC-szint-meghatározás a klinikum számára közvetlen haszonnal bírjon, terápiás tartományok megállapítása szükséges. Az évek alatt szerzett tapasztalatok alapján ma már olyan terápiás tartományok állnak rendelkezésre, amelyeket alkalmazhatunk a különböző klinikai szituációkban [39, 40, 44, 46]. Meg kell jegyezni azonban, hogy e kérdés ma még nem annyira letisztázott, mint a K-vitamin-antagonisták esetében alkalmazott INR-tartományok esetén (4. táblázat).

\section{A gyógyszerek monitorizálásának alapelvei}

A gyógyszerek hatékonyságának ellenőrzésére a legplauzibilisebb módszer a biológiai monitorizálás, mint például az antihipertenzív kezelés során történő vérnyomásmérés vagy az antidiabetikumok adásakor történő glükóz- és hemoglobin-Alc-meghatározás.

A klasszikus gyógyszer-koncentráció, vagyis a tömegegységekben immunoassayvel vagy valamilyen elválasztástechnikai módszerrel történő gyógyszerszint-meghatározás is általános gyakorlat például immunszuppresszív készítmények, antiepileptikumok, anbiotikumok, kardioaktív szerek, teofillin, metotrexát és számos egyéb gyógyszercsoport esetén. Amint az előbbiekben is vázoltuk, a hemosztatikus rendszerre ható gyógyszerek monitorizálása azok funkcionalitását használja ki a kumarin- és heparinkészítményeknél és ugyanez igaz a NOAC-monitorizálásra is. Minden esetben érvényesül azonban az egyéb 
4. táblázat $\mid$ A NOAC-készítmények jellegzetes völgy- és csúcskoncentrációtartományai

\begin{tabular}{llll}
\hline Készítmény & Dózis & $\mathrm{C}_{\mathrm{csúcs}}(\mu \mathrm{g} / \mathrm{L})$ & $\mathrm{C}_{\mathrm{völgy}}(\mu \mathrm{g} / \mathrm{L})$ \\
\hline Dabigatran & $2 \times 150 \mathrm{mg}$ & $64-443$ & $31-225$ \\
\hline Rivaroxaban & $1 \times 20 \mathrm{mg}$ & $160-400$ & $10-100$ \\
& $1 \times 10 \mathrm{mg}$ & $100-200$ & $1-38$ \\
\hline Apixaban & $2 \times 10 \mathrm{mg}$ & $100-400$ & $30-400$ \\
& $2 \times 5 \mathrm{mg}$ & $91-321$ & $20-230$ \\
\hline Edoxaban & $1 \times 60 \mathrm{mg}$ & $120-250^{*}$ & $10-62^{*}$ \\
\hline
\end{tabular}

A táblázatban feltüntetett (5-95. percentilis) értékek nonvalvularis pitvarfibrillációban szenvedő betegek stroke-profilaxisa, illetve mélyvénás thrombosis és tüdőembolia megelőzésére vonatkoztatott, több tanulmány áttekintése alapján javasolt tartományok $[9,10,14,16]$. Egyéb indikációkban ettool eltérő tartományokat is közöltek [9]. A fel nem tüntetett dózisok esetén nem rendelkezünk elegendő adattal ahhoz, hogy terápiás tartományt adjunk meg.

*Interkvartilis tartomány (25-75. percentilis).

$\mathrm{C}_{\mathrm{csúcs}}=$ csúcskoncentráció; $\mathrm{C}_{\mathrm{völgy}}=$ völgykoncentráció

gyógyszerek monitorizálásánál is ismert gyakorlat, vagyis, hogy az optimális időpont bevétel előtti minta (völgykoncentráció), illetve, hogy az orálisan szedett készítmény esetén a gyógyszer féléletidejének ötszöröse alatt alakul ki az egyensúlyi állapot, és a gyógyszer ugyanennyi idő alatt is ürül ki a szervezetből, ami mindössze kéthárom nap.

\section{A laboratóriumi monitorozás módszerei NOAC-terápia esetén; preanalitikai, analitikai szempontok}

A rutinlaboratóriumok számára ma elérhető módszertant alkalmazva a NOAC-szint-meghatározásra alkalmas minta a Na-citráttal antikoagulált vérmintából (kék kupakos vakuténer cső) szeparált thrombocytaszegény plazma. Amennyiben csúcskoncentráció meghatározására van igény, akkor a vért az utolsó dózis bevétele után 2-4 órával kell levenni, amennyiben a völgykoncentráció meghatározása a cél, akkor pedig a következő dózis bevétele előtt, azaz napi egyszeri adagolású készítménynél 20-24 órával az utolsó dózis bevétele után, napi kétszeri adagolású gyógyszer esetén pedig 10-12 órával az utolsó dózis bevétele után. A levett vérmintákat a lehető leghamarabb (2 órán belül) el kell juttatni a laboratóriumba, ahol megtörténik a thrombocytaszegény plazma szeparálása. A plazmaminták stabilitására vonatkozóan ma még nincs egyértelmû ajánlás, azonban a rutin-hemosztázislaboratóriumok gyakorlata szerint, amennyiben nem azonnal történik meg a minták mérése, a plazmát fagyasztani kell és a mérés kivitelezhető a felolvasztott plazmamintából is. A fagyasztott plazma eltarthatóságával kapcsolatban nincsenek tanulmányok, azonban feltételezhető, hogy egyéb paraméterekhez hasonlóan egykét hónapig stabil a minta.
A NOAC-plazmakoncentráció meghatározásának arany standardja a folyadékkromatográfia-tandem tömegspektrometria (LC-MS/MS) módszer [47-49]. Ezzel a módszerrel a plazmában jelen lévő NOAC koncentrációját állapíthatjuk meg pontosan, jól reprodukálhatóan, szelektíven, azaz egyéb jelen lévő plazmakoaguláció-inhibitoroktól függetlenül. Ezt a módszert alkalmazták a gyógyszerek fejlesztése során és a legtöbb klinikai gyógyszervizsgálat esetében is. A módszer elterjedésének legfóbb korlátja a speciális múszerigénye, ami nagyon drága és a bonyolult technika, amely szakképzett személyzet meglétét feltételezi. Hiányzik továbbá a módszer standardizációja, ami a laboratóriumok között igen nagy variabilitást eredményez. A rutinlaboratóriumokban ez a technika nem is terjedt el, azonban az alább ismertetett tesztek kidolgozásában fontos szerepet játszott/játszik mint referenciamódszer.

A rutinlaboratóriumokban ma elérhető és legszélesebb körben alkalmazott NOAC-szint-mérési módszerek valójában nem magát a gyógyszer-koncentrációt határozzák meg, hanem a gyógyszerek hatását mérik. Ez fontos koncepcionális különbség az LC-MS/MS módszerrel szemben; egyrészt a hatás mérése funkcionális tesztben valósabb képet ad az adott gyógyszer adott szervezetre kifejtett hatásáról, mint magának a koncentrációnak a mérése, másrészt viszont a funkcionális tesztekkel kapott eredményeket magának a gyógyszernek a hatása mellett egyéb tényezők is befolyásolhatják (például a gyógyszer által gátolt alvadási faktorra ható egyéb inhibitorok).

A könnyebb áttekinthetôség kedvéért célszerű a dabigatran meghatározásának módszereit a X-es faktort gátló készítmények mérését célzó módszerektől elkülönítve tárgyalni.

\section{A dabigatranszint mérésére alkalmas módszerek}

A direkt trombininhibitorok hatásának követésére ma két laboratóriumi metodika elfogadott, az alvadási idő alapú és a kromogén esszé (1. ábra).

Az alvadási idő meghatározásán alapuló jelenleg legelterjedtebb módszer tulajdonképpen trombinidőmérést jelent, azonban, mivel a hagyományos trombinidő túlságosan érzékeny a dabigatran jelenlétére, módosított trombinidő-meghatározást alkalmazunk. A módosítás azt jelenti, hogy a vizsgálandó plazmát (ami tartalmazza a dabigatrant) pufferrel hígítjuk (általában 1:8 arányban), majd a hígított plazmát normál poolozott plazmával 1:1 arányban keverjük. Ehhez a keverékhez adjuk a trombinoldatot, majd regisztráljuk az alvadási időt. Az így módosított trombinidő-meghatározás során kapott alvadási idő értéke a plazma növekvő dabigatrankoncentrációjával lineáris összefüggést mutat és megfelelő, ismert dabigatrankoncentrációjú plazmával történő kalibrálást alkalmazva az alvadási idő dabigatrankoncentráció értékké konvertálható [50-52]. A fenti módszerrel relatíve széles koncentrációtartományban tudunk dabigatran-plazmaszintet kvantifikálni, a kereskedelmi for- 
A

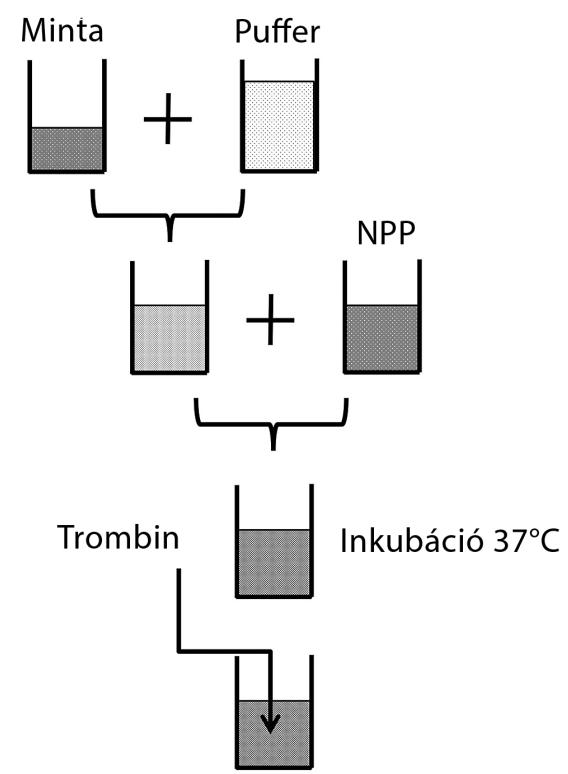

Alvadási idő detektálása (s)
B

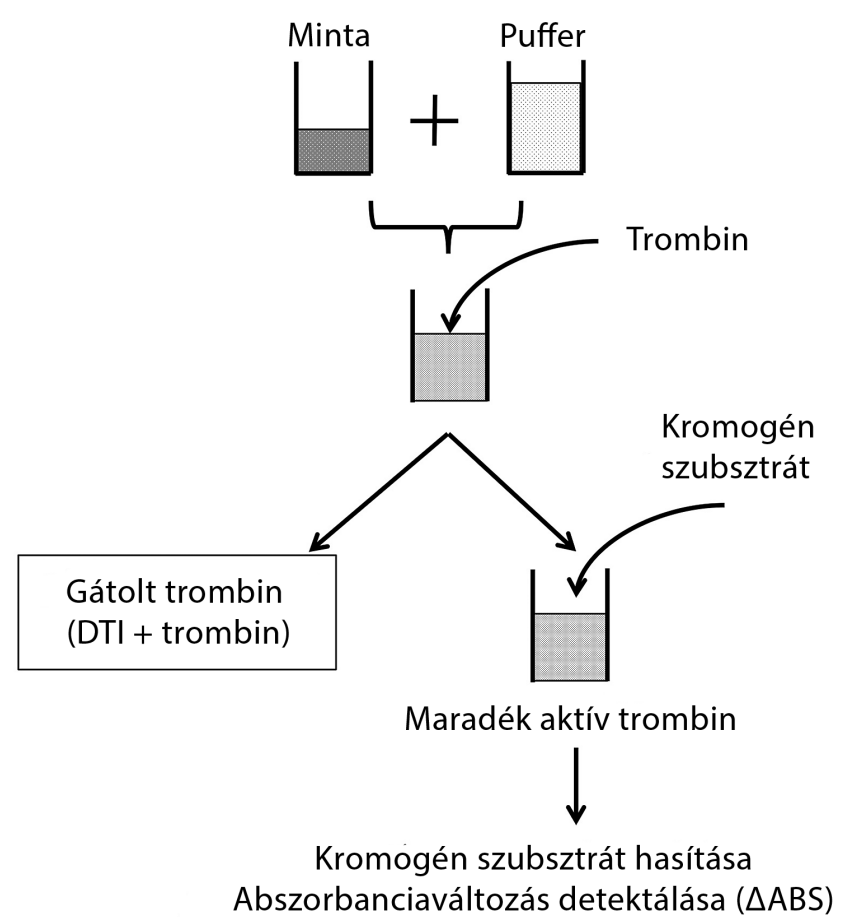

1. ábra Direkt trombininhibitor (dabigatran) meghatározásának módszerei. 1/A: Hígított trombinidő alapú módszer. 1/B: Kromogén esszé
DTI = direkt trombininhibitor (dabigatran); kromogén szubsztrát = olyan rövid, néhány aminosavból álló peptid és a hozzákapcsolt, kötött állapotban
színtelen vegyület, amelyet a vizsgálandó enzim (jelen esetben a trombin) képes hasítani, a hasítás színreakcióval jár; NPP = normál poolozott plazma

galomban kapható kiteket alkalmazva általában 50-500 ug/L között.

Az alvadási idő meghatározásán alapuló módszerek másik típusa az úgynevezett ekarin alvadási idő alapú teszt, ahol a fenti módszerhez igen hasonlóan az alvadási idő értékét konvertáljuk dabigatrankoncentrációvá megfelelő kalibrátor alkalmazásával, csak ez esetben az alvadás aktivátora trombin helyett ekarin [53]. Az ekarin egy vipera (Echis carinatus) mérgéből származó metalloproteáz, ami a protrombin-meizotrombin átalakulást katalizálja. A meizotrombin egy hatékony trombin-intermedier, amit a dabigatran szintén képes gátolni, így az ekarin alvadási idő megnyúlása lineárisan követi a plazma dabigatrankoncentrációját.

A jelenleg kereskedelmi forgalomban kapható kitek közül a Hemoclot-teszt (Hyphen), a HemosIL DTI (Werfen) és a Technoclot DTI (Technoclone) a trombinidő alapú, míg a Stago cég kitje az ekarin alvadási idő alapú teszteket képviseli.

A kromogén teszt lényege, hogy a vizsgálandó, dabigatrant tartalmazó plazmához feleslegben adunk trombint és a trombinra specifikus kromogén szubsztrátot, amelyet a trombin aktivitásától függő mértékben képes elhasítani, ami ANBA (5-amino-2-nitro-benzoicacid) -felszabadulással jár, ez pedig $405 \mathrm{~nm}$-en követve abszorbanciaváltozást okoz ( $1 / B$ ábra). Minél több kromogén szubsztrát kerül hasításra, annál jelentôsebb az abszorbanciaváltozás. Minél magasabb a dabigatran kon- centrációja, annál több hozzáadott trombin kerül gátlás alá, azaz annál kevesebb lesz az elhasított kromogén szubsztrát mennyisége, ezáltal az abszorbanciaváltozás mértéke. Adekvát, a teszthez kínált kalibrátort alkalmazva az abszorbanciaváltozás dabigatrankoncentrációvá konvertálható. E módszeren alapul az Innovance DTI (Siemens, https://w5.siemens.com/belux/web/nl/ healthcare/news-events/conferences/Documents/ 2-1_INNOVANCE_DTI.pdf) kitje, amelynek mérési tartománya 20-500 $\mu \mathrm{g} / \mathrm{L}$ és a Hyphen Biomed DTI reagens [54]. Az ekarin aktivátort kromogén tesztben is lehet alkalmazni, ilyen elven mér a Stago ECA-T Dabigatran kit (https://www.stago.com/products-services/new-products/detail/article/a-reagent-to-measuredabigatran-pradaxaR/).

\section{A direkt FXa-gátló készítmények szintjének mérésére alkalmas módszerek}

E gyógyszerek hatásának követésére az LMWH-készítményeknél alkalmazott, jól ismert anti-FXa-módszer ajánlott, ahol a vizsgálandó, direkt FXa-gátló készítményt tartalmazó plazmához aktív X-es faktort (FXa) és annak specifikus, kromogén szubsztrátját adjuk feleslegben [55-60]. A kromogén szubsztrát hasításának mértéke fordítottan arányos a plazma gyógyszer-koncentrációjával (2. ábra). A kromogén szubsztrát elhasítását abszorbanciaváltozás jelzi, amely megfelelő kalibrátor alkalmazásával rivaroxaban- vagy apixabankoncentráció- 
A

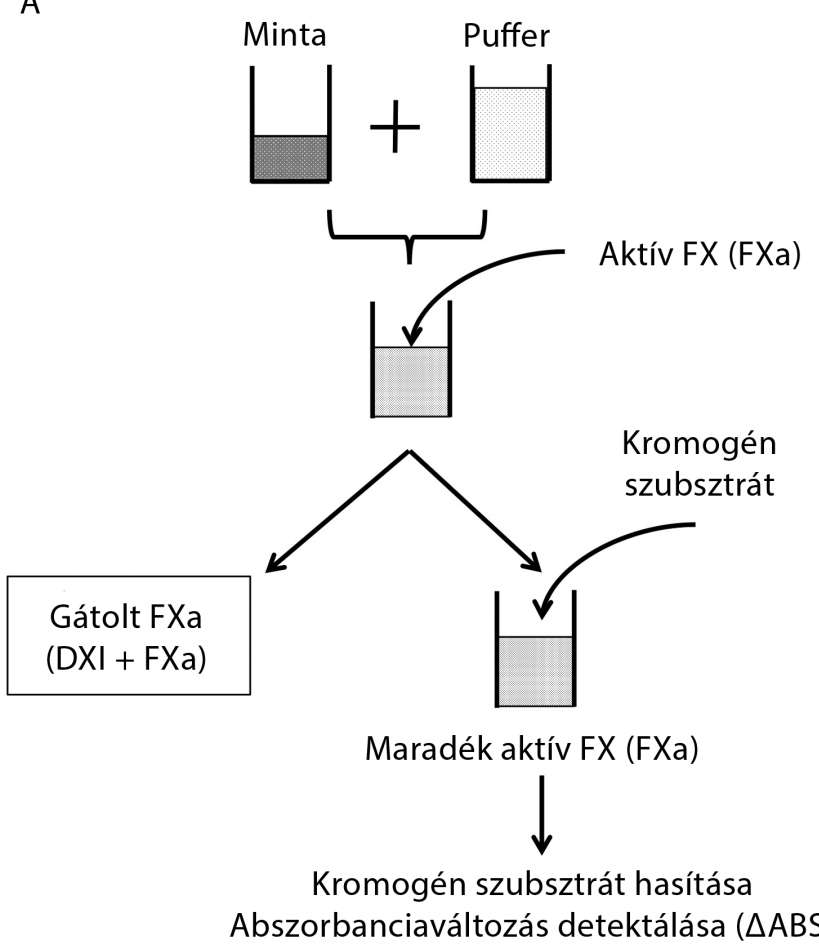

B

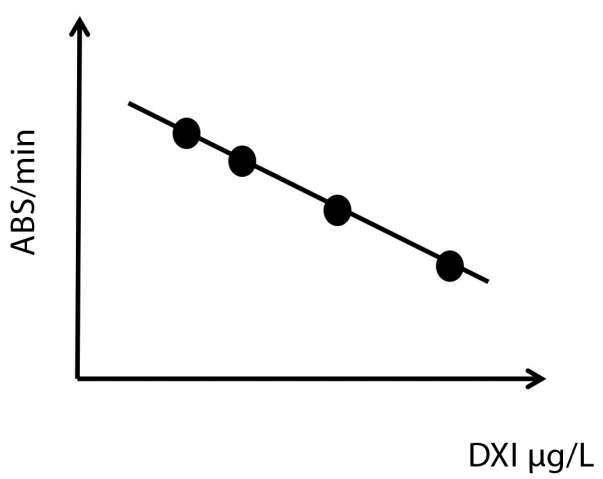

2. ábra

| Direkt FXa-inhibitorok meghatározásának módszere. 2/A: Kromogén esszé. 2/B: Az esszé tipikus kalibrációs görbéje

DXI = direkt FXa-gátló (például rivaroxaban); kromogén szubsztrát = olyan rövid, néhány aminosavból álló peptid és a hozzákapcsolt, kötött állapotban színtelen vegyület, amelyet a vizsgálandó enzim (jelen esetben az FXa) képes hasítani, a hasítás színreakcióval jár; FXa = aktív X-es faktor

vá konvertálható. A különböző módszerek általában 15-1000 $\mathrm{gg} / \mathrm{L}$ tartományban detektálnak és jól korrelálnak a referenciamódszerként hivatkozott LC-MS/MS módszerrel [61]. Fontos kiemelni, hogy a „hagyományos", LMWH esetében alkalmazott anti-FXa-teszt, amely heparintartalmú kalibrátort tartalmaz, nem ad megbízható eredményt a direkt FXa-gátlók vonatkozásában, ezért nem ajánlott! Mivel többféle FXa-gátló is forgalomban van, figyelni kell arra is, hogy az adott gyógyszer hatásának mérését csakis az adott gyógyszert tartalmazó kalibrátorral szabad használni (rivaroxabanrivaroxaban kalibrátor, apixaban-apixaban kalibrátor), ellenkező esetben inadekvát eredményt kapunk. Ma a Technoclone, Hyphen, Siemens, Stago és Werfen cégek terméklistájában találunk direkt FXa-meghatározásra alkalmas kiteket. E kézirat írásakor edoxaban- és betrixabankalibrátorok még nem érhetőek el széles körben. Azt érdemes szem előtt tartani, hogy az anti-FXa-tesztek eredményét a heparin és heparinszerü anyagok jelenléte befolyásolja, így amennyiben a beteg esetleg heparint és direkt FXa-gátlót is kap, egyik gyógyszer koncentrációját sem határozhatjuk meg pontosan.

Mind a dabigatran, mind a direkt FXa-gátlók meghatározásával kapcsolatban kiemelendő, hogy a laboratóriumnak (egyéb laboratóriumi módszerekhez hasonlóan) kötelező a belső minőségi kontroll alkalmazása és ajánlott külső minőségi körkontrollrendszerben is részt venni. A hemosztázis szakterületen Európában az ECAT és a NEQAS nemzetközi körkontrollrendszerek a legismer- tebbek; mindkét szervezet kínál NOAC-platformot, és a jelentkező laboratóriumok száma évről évre ugrásszerüen nő (www.ecat.nl és www.ukneqas.org.uk). Az ECAT programban 2017-ben már 200-nál több laboratórium vett részt dabigatran, rivaroxaban és apixaban meghatározásában. A fenti módszereket alkalmazva a laboratóriumok közötti variabilitás meglehetősen jónak, mindöszsze 8-11\% körülinek bizonyul. (Összefoglalóan lásd a 4 . táblázatot!)

Mivel a fenti, adekvát, kvantitatív eredményt adó tesztek általában nem elérhetőek sürgősségi körülmények között a laboratóriumokban, újabban történnek próbálkozások point-of-care tesztek (POCT) kidolgozására is. Ezek közül egyelőre a vizeletmintában dabigatran, rivaroxaban és apixaban kimutatására csak kvalitatív eredményt biztosító POCT-teszt jelent meg [62]. Próbálkozások vannak továbbá a trombingenerációs teszt, illetve a rotációs tromboelasztográf (ROTEM) beállítására, de ezek a törekvések egyelőre nem hoztak kielégítő eredményeket [63-67].

\section{A NOAC-készítmények hatása a hemosztázis szürőtesztjeire}

A NOAC-készítmények nem igényelnek rutinlaboratóriumi monitorozást, ugyanakkor komoly kihívás elé állítják a laboratóriumokat azzal, hogy bár ritka, de igen jelentős klinikai igény sürgősségi esetekben a NOAC 
jelenlétének és hatásának laboratóriumi megítélése, valamint azzal, hogy a NOAC-készítmények betegmintában való jelenléte interferálhat számos rutin és speciális alvadási tesztben, azok interpretációját nehezítve. A NOACkészítmények véralvadási szűrőtesztekre való hatását csoportonként tárgyaljuk, bár a direkt FXa-gátlók, a várttal ellentétben, nem azonos hatást okoznak a hemosztázis szürőtesztjeiben.

\section{Direkt trombingátláson alapuló NOAC - dabigatran - hatása a hemosztázis szürőtesztjeire}

Általánosságban elmondható, hogy dabigatran jelenlétében valamennyi koagulációs szûrôteszt megnyúlhat. Az aktivált parciális tromboplasztin idő (APTI) érzékenyebben jelzi dabigatran jelenlétét, mint a protrombinidő (PI). A trombinidő (TI) megnyúlása extrém fokú, de a rutin méréstartomány felett a dabigatran koncentrációjával lineáris és dózisfüggő [68].

Az APTI dabigatran terápiás dózisa mellett, még völgykoncentrációban is, általában megnyúlik, és a különböző reagensekkel kapott APTI-eredmények varianciája relatíve kicsi [69]. Ugyanakkor a dabigatran nem mindig nyújtja az APTI-t a normáltartomány felső határa felé. Egy tanulmány szerint napi kétszer $150 \mathrm{mg}$ dabigatran mellett, az adag bevétele után 2-3 órával vett mintákban - bár LC-MS/MS módszerrel terápiás dabigatrankoncentráció volt detektálható -, a betegek 18\%-ában az APTI-t normálnak találták [70]. Egy másik tanulmányban pedig még $100 \mu \mathrm{g} / \mathrm{L}$ feletti plazmakoncentrációknál sem volt APTI-megnyúlás, reagenstől függően a betegek 15-35\%-ánál [68]. A dabigatran koncentrációja és az APTI-megnyúlás dózis-hatás görbéje elhajló lineáris, amely ellaposodik a magasabb koncentrációtartományban [69]. Mindezek alapján és mivel az APTI-megnyúlás nem specifikus dabigatran jelenlétére, az APTI nem alkalmas a dabigatrankoncentráció kvantifikálására.

A dabigatran PI-nyújtó hatása kevésbé jellemző, mint az APTI-t megnyújtó hatás. A PI a 150 mg dabigatrant naponta kétszer szedőktől a gyógyszer bevételét követő 2-3 óra múlva vett minták 29\%-ában nem mutatott megnyúlást [70]. A hazánkban nem alkalmazott Owren PI-módszerek (például Thrombotest) nagyobb tesztplazma hígítással dolgoznak, így kevésbé mutatnak interferenciát (megnyúlást) dabigatran jelenlétében, mint a nálunk alkalmazott PI-mérési módszerek. Vannak esetismertetések, ahol dabigatran jelenlétében jelentős PI/ INR emelkedés volt detektálható bizonyos módszerekkel, így egy point-of-care (POC-) módszerrel és a Hemochron Jr Signature eszközzel. A Hemochron Jr Elite POC-analizátor érzékenyebben jelezte a dabigatrant, mint öt hagyományos központi laboratóriumi PI-módszer egy „ex vivo” végzett tanulmány eredményei szerint [70]

A DTI dabigatran hatása olyan tesztekben, ahol trombint adunk a plazmához a reagensben (például trombin- idő és Clauss fibrinogénteszt), attól függ, hogy mennyi a reagensben hozzáadott trombin koncentrációja és attól, hogy milyen mértékben hígítjuk elő a plazmát. A hagyományos trombinidőtesztek nagyon érzékenyek dabigatranra: nagyobb mint tízszeres megnyúlást okoznak dabigatran csúcskoncentrációja mellett [71], ami nem normalizálódik völgykoncentrációnál sem. Egy másik „in vitro” tanulmány megfigyelése szerint, $25 \mu \mathrm{g} / \mathrm{L}-150$ $\mu \mathrm{g} / \mathrm{L}$ dabigatrankoncentráció-tartományban módszertől függően a plazmák nem alvadtak meg TI-mérés során [72]. Az eddig tanulmányozott módszerek esetén a normál TI alapján a klinikailag releváns mennyiségű dabigatran jelenléte kizárható $[70,72]$. Clauss fibrinogéntesztek előhígítás nélkül kissé alábecslik a fibrinogén koncentrációját dabigatran jelenlétében. Magasabb trombinkoncentrációt és/vagy nagyobb plazma-előhígítást alkalmazó módszerek (1:10 hígítás vagy nagyobb) nagyjából függetlenek dabigatran jelenlététől $500 \mu \mathrm{g} / \mathrm{L}-1000$ $\mu \mathrm{g} / \mathrm{L}$ dabigatrankoncentrációig [69]. A dabigatranhemosztázis szûrőtesztekre gyakorolt hatásait az 5. táblázat tartalmazza.

\section{Direkt FXa gátló NOAC - rivaroxaban, apixaban, edoxaban - hatása a hemosztázistesztekben}

A direkt FXa-gátló NOAC alvadási szúrőtesztekre gyakorolt hatását vizsgáló tanulmányok zöme rivaroxaban vizsgálatából származik, amelyek nagy része úgynevezett „spiking study”, amikor direkt FXa-gátló NOAC-készítménnyekkel „in vitro” szupplementált plazmákon végezték a vizsgálatokat, nem pedig direkt FXa-gátló NOAC-készítményt szedő betegek mintáin. Az eddigi tanulmányok tapasztalata alapján elmondható, hogy a PI-reagensek jelentősebb, koncentrációfüggő megnyúlással jeleznek anti-FXa-inhibitor NOAC jelenlétében, mint az APTI-reagensek, de ez a megnyúlás különböző anti-FXa-inhibitor NOAC-készítmények esetén érdemben eltérő, ugyanakkor jelentősen reagensfüggő, továbbá függ attól, hogy ,in vivo” vagy ,in vitro” került a direkt FXa-gátló NOAC a plazmába [68, 73].

$\mathrm{Az}$ apixaban terápiás koncentrációban nincs lényeges hatással az APTI-re, $200 \mu \mathrm{g} / \mathrm{L}$ apixabankoncentráció

\begin{tabular}{lll} 
5. táblázat & $\begin{array}{l}\text { NOAC-készítmények hemosztázisszúró tesztekre gyakorolt ha- } \\
\text { tása }\end{array}$ \\
\hline Teszt & DTI & Direkt FXa-inhibitor \\
\hline PI & Norm- $\uparrow$ & Norm- $\uparrow^{1,2}$ \\
APTI & Norm- $\uparrow^{1}$ & Norm- $\uparrow^{2}$ \\
TI & $\uparrow \uparrow \uparrow$ & Nem befolyásolja \\
Clauss fibrinogén & $\begin{array}{l}\text { Nincs hatása vagy } \\
\text { minimális alámérés }\end{array}$ & Nem befolyásolja \\
\hline
\end{tabular}

APTI = aktivált parciális tromboplasztin idő; DTI = direkt trombinin hibitor; $\mathrm{PI}=$ protrombinidő; $\mathrm{TI}=$ trombinidő; $\uparrow$ az alvadási idő enyhe megnyúlása; $\uparrow \uparrow$ az alvadási idő mérsékelt megnyúlása; $\uparrow \uparrow \uparrow$ az alvadási idő jelentôs megnyúlása; ${ }^{1}$ reagensfüggő hatás; ${ }^{2} \mathrm{az}$ apixabannak nincs vagy csekély hatása van; ${ }^{3}$ módszerfüggő hatás, legtöbb fibrinogén tesztet nem befolyásolja 
mellett némi APTI-megnyúlás volt tapasztalható öt különböző APTI-reagenssel. Az apixaban terápiás koncentrációban alig nyújtja meg a PI-t, $200 \mu \mathrm{g} / \mathrm{L}$ apixabankoncentráció mellett hét reagensból hat esetében a PI megnyúlása minimális volt [69]. Ezzel szemben a rivaroxaban és az edoxaban gyakran megnyújtja mind a PI-, mind az APTI-teszt eredményét [68]. Az apixaban hatása az APTI- és PI-tesztekre tehát sokkal kevésbé kifejezett, mint a rivaroxabané és az edoxabané $[55,68]$. A különbségek oka egyelőre nem ismert. Tehát az APTIés PI-reagensek különböző érzékenységgel nyúlhatnak meg direkt FXa-gátlók jelenlétében és a legtöbb PI érzékenyebb a direkt FXa-gátlókra, mint az APTI-reagensek. Azonban azok az APTI-ráták és INR-tartományok, amelyeket UFH és hagyományos orális antikoagulánsok (Syncumar) alkalmazási biztonság mértékének megítélésére állapítottak meg, nem alkalmasak direkt FXa-gátló terápia biztonságának és hatásosságának megítélésére [69].

A direkt FXa-gátló NOAC-készítmények reagensfüggésével kapcsolatban sok közlés van. Így ismert, hogy rivaroxabanfüggő PI-megnyúlás kevésbé figyelhető meg Owren-módszer elvével mérő PI-reagensekkel (amelyeknél a plazma és így a benne levő gyógyszerek előhígításra kerülnek), mint a hazánkban alkalmazott Quick PImódszereknél. Innovinnal (Siemens, Marburg, Németország) és Thromborel S reagenssel (Siemens) normál PI-t találtak egészen $270 \mu \mathrm{g} / \mathrm{L}$ rivaroxabankoncentrációig, egy rivaroxabankezelt beteg többszöri mintavételezése során, akinek terápia előtti PI-ideje a normál tartomány alsó határán volt [74]. Ugyanakkor Recombiplastin $2 \mathrm{G}$ érzékeny rivaroxaban jelenlétére: rivaroxabanterápia alatt álló 31 beteg 33 mintájából mért PI közül azon 10 minta rivaroxabankoncentrációja, amely normál PI-t adott, $90 \mu \mathrm{g} / \mathrm{L}$ rivaroxabankoncentráció alatti volt [75]. A magasabb koncentrációk mind PI-megnyúlást okoztak [75]. Tovább nehezíti a kérdést, hogy többszörösen ellentmondásos eredmények vannak STA-Neoplastine CI Plus (Stago, Asnières sur Siene, Franciaország) esetében, ahol rivaroxabant szedő betegek mintáin egyik tanulmányban megnyúlt PI-ket, míg egy korábbiban normál PI-ket mértek rivaroxaban terápiás koncentrációi mellett, miközben a STA-Neoplastine CI Plus reagens mutatta a legnagyobb rivaroxabanérzékenységet, amikor rivaroxabannal laboratóriumban szupplementált mintákon végezték a tanulmányt [69]. Addig, amíg nincs több olyan tanulmány, amelyet olyan betegek mintáin végeztek, akik direkt FXa-gátló NOAC-kezelés alatt állnak, addig az individuális beteg terápia előtti PI-értéke segít a kezelés során mért PI-értékek interpretálásában.

Szintén felmerült PI-módszer-specifikus rivaroxabanérzékenységi index (ISI) képzése, amely segíthetné a rivaroxabanra különböző érzékenységü PI-reagensekkel kapott PI-megnyúlások normalizálását [76, 77], ez azonban még nem ajánlott.

Bár a PI érzékenyebb direkt FXa-gátló NOAC-készítmények jelenlétére, ugyanakkor normál PI sem zárja ki a direkt FXa-gátló NOAC betegmintában való jelenlétét. Egy vizsgálat során a terápiás rivaroxabantartományban levő betegek 32\%-ánál normál PI-t mértek [78].

A direkt FXa-gátló NOAC-készítményeknek nincs hatása a trombinidőre, sem a Clauss-módszerrel történő fibrinogénmeghatározásra [69].

A direkt FXa-gátló NOAC-készítmények rutin-hemosztázistesztekre gyakorolt hatását az 5. táblázat tartalmazza.

\section{Összegzés}

Az orális DTI dabigatran jelenlétében valamennyi alvadási szúrőteszt megnyúlhat (PI, APTI, TI).

Az APTI érzékenyebben jelzi dabigatran jelenlétét, mint a PI. Mindkettő azonban reagensfüggő, PI-módszerfüggő (hazánkban alkalmazott Quick-módszer érzékenyebb).

Sem normál PI, sem normál APTI nem zárja ki dabigatran terápiás dózisban való jelenlétét. Még 100 $\mu \mathrm{g} / \mathrm{L}$ feletti plazmakoncentrációknál sincs biztosan APTI-megnyúlás.

A TI megnyúlása dabigatran jelenlétében extrém fokú. A normál trombinidő arra utal, hogy a dabigatran koncentrációja igen alacsony, nincs érdemi hatás.

Az orális direkt FXa-gátló rivaroxaban, apixaban, edoxaban esetén PI, APTI megnyúlik, de a TI-re nincs hatása. PI-reagensek jelentősebb, koncentrációfüggő megnyúlással jeleznek direkt FXa-gátló NOAC jelenlétében, mint az APTI-reagensek, de ez a megnyúlás különböző direkt FXa-gátló NOAC-készítmények esetén érdemben eltérő, ugyanakkor jelentősen reagensfüggő, továbbá függ attól, hogy „in vivo” vagy „in vitro” került a direkt FXa-gátló NOAC a plazmába.

Rivaroxabanra és edoxabanra a PI általában érzékenyebb, mint az APTI, amely utóbbi nem alkalmas a gyógyszer koncentrációjának mérésére.

Apixabanra a PI és az APTI érzéketlen, és a betegek terápiás apixabankoncentráció mellett is normál PI- és APTI-értékeket mutatnak.

Néhány betegnek terápiás rivaroxabankoncentráció mellett is normál a PI- vagy APTI-értéke.

\section{A NOAC-készítmények hatása a hemosztázis egyéb tesztjeire}

Mind a dabigatran, mind a direkt FXa-gátló készítmények hatással vannak számos, a hemosztázislaboratóriumban mért paraméterre. A koaguláció szűrőtesztjeinek befolyásolása mellett többé-kevésbé minden olyan teszttel interferálnak, ami alvadási idő meghatározásán alapszik. Elsőként érdemes megemlíteni a fibrinogénmeghatározást, amit általában Clauss-módszerrel mérnek. Ez voltaképpen trombinidő-meghatározásra vezethető vissza, ezért logikus, hogy a dabigatran - trombinidőmegnyúlást okozó markáns hatása miatt - alámérést 
okoz a Clauss-fibrinogéntesztben. Saját laboratóriumunkban tapasztaltak alapján a dabigatrankoncentráció $200 \mu \mathrm{g} / \mathrm{L}$ feletti plazmaszintje esetén a fibrinogénkoncentráció 10\%-os alámérését, $400 \mu \mathrm{g} / \mathrm{L}$ feletti érték esetén 30\%-os alámérését okozza. A változás mértéke természetesen függ az adott laboratórium által használt fibrinogénreagensben lévő trombin koncentrációjától, a vizsgálandó plazma hígításától stb., ezért fenti észrevételek nem általánosíthatók, és minden laboratóriumnak tisztában kell lenni saját reagensének dabigatranérzékenységével. A fibrinogénkoncentrációt a direkt FXagátló készítmények nem befolyásolják. A fibrinogénszint immunológiai módszerrel történő meghatározására (például immunnefelometria) egyik NOAC sem hat, így természetesen a dabigatran sincs hatással. A reptiláz idő vizsgálata heparinterápia esetén jól elkülöníti a gyógyszer által okozott trombinidő-megnyúlást a hypo-, dys- vagy afibrinogenaemiától. Reptiláz idő ezen kórképekben megnyúlást mutat, heparin hatására azonban nem, így dabigatran esetében is hasonlóképpen normál eredményt ad [79]. (Direkt FXa-készítményeknél nem releváns a vizsgálata, hiszen trombinidő-megnyúlás sincs, de egyébként normál eredményt ad.)

A hemosztázislaboratóriumokban számos további paraméter meghatározása alvadási idő mérésére vezethető vissza. Mivel az alvadási idő értékekeit az adott NOACkészítmény az adott tesztben alkalmazott reagensektől függő mértékben befolyásolja, a meghatározni kívánt paraméterrel interferál fals alá- vagy fölémérést okozva. Az alvadási faktorok aktivitásának meghatározására világszerte az egyfázisú alvadási tesztek terjedtek el. Mind a direkt FIIa-, mind a direkt FXa-gátlók interferálnak e meghatározásokkal, fals alacsony faktorszinteket eredményezve [80-82].

Gyakori helyzet, hogy a thromboticus eseményen átesett és már antikoaguláns terápiára állított betegnél kívánják a thrombophilia irányú vizsgálatokat kivitelezni. Egyik ilyen problémás helyzet a lupus anticoagulans (LA) jelenlétének megítélése NOAC-terápia mellett. Több tanulmányban kimutatták, hogy mind a dabigatran, mind direkt FXa-gátló készítmények befolyásolják az LA kimutatására használt laboratóriumi teszteket (fals pozitivitást okozva) már nagyon alacsony, detektálásái határ alatti plazmakoncentrációk esetén is, ezért az LAvizsgálatokat egyáltalán nem javasolják NOAC mellett elvégezni [83].

A veleszületett thrombophilia vizsgálatakor az antitrombin-aktivitás meghatározása dabigatran mellett nem ajánlott, ha a teszt a FIIa gátlásán alapul, és nem ajánlott direkt FXa-gátlók mellett antitrombin-aktivitást mérni, ha a teszt az FXa gátlásán alapul [68]. A protein C és S aktivitásának meghatározására használt alvadási idő alapú tesztek fals negatív eredményt adhatnak (azaz a valósnál magasabb protein C- és S-aktivitási értékeket mutatnak) minden NOAC esetén, míg a protein C kromogén funkcionális tesztet és a szabad protein $S$ antigén meghatározására alkalmas immunturbidimetriás módszert a gyógy- szerek nem zavarják. Az aktivált protein C-rezisztencia (APC-rezisztencia) funkcionális tesztet minden NOAC befolyásolja a tesztben alkalmazott alvadási idő (általában APTI) megnyúlás mértéke szerint általában fals magas rátákat eredményezve. Az FV Leiden-mutáció és a protrombin $20210 \mathrm{G}>\mathrm{A}$ polimorfizmus genetikai vizsgálatát természetesen a NOAC-terápia nem befolyásolja. Összességében megállapítható, hogy NOAC-terápián lévő betegnél az antitrombin-, protein C- és S-szintek, az APC-rezisztencia funkcionális teszt és az LA-irányú vizsgálat eredményei nem megbízhatóak, ezeket nem javasoljuk vizsgálni; illetve javasoljuk, hogy a klinikusok a vizsgálatokat végző laboratórium szakmai álláspontjának megfelelően járjanak el. Amennyiben a vizsgálatok kedvéért az antikoagulálás nem hagyható el, LMWH-terápia mellett javasoljuk kivitelezni azokat, mert e készítmények mellett elhanyagolható az interferencia.

Érdemes figyelembe venni azt is, hogy a globális hemosztázisteszteket (trombingenerációs esszé, ROTEMteszt) a NOAC-készítmények érthető módon szintén befolyásolják, hiszen csökkentik a képződött trombin mennyiségét.

Ezen számos paraméter mellett azért vannak olyan vizsgálatok is, amelyek elvégzése miatt nem szükséges a NOAC elhagyása vagy helyettesítése LMWH-val [84]. Ezek az immunológiai módszertant alkalmazó tesztek (például D-dimer-meghatározás, von Willebrand-antigén-meghatározás), a thrombocytafunkció vizsgálatának tesztjei (PFA-100-záródási idő, thrombocytaaggregáció és -szekréció vizsgálata - bár a trombin indukálta thrombocytaválaszokra hatással lehet a dabigatran), a von Willebrand-betegség kivizsgálásának funkcionális tesztjei és az összes molekuláris genetikai vizsgálat.

Anyagi támogatás: A közlemény elkészítését az OTKA Kl16228 számú pályázat támogatta.

Szerzôi munkamegosztás: B. Zs., A. É.: A laboratóriumi monitorizálásra vonatkozó részek elkészítése. O. Zs.: A terápiás vonatkozású fejezetek megírása. K. J.: A közlemény első vázlatának elkészítése, a cikk utolsó verziójának kialakítása és ellenőrzése. A cikk végleges változatát valamennyi szerző elolvasta és jóváhagyta.

Érdekeltségek: A szerzőknek nincsenek érdekeltségeik.

\section{Köszönetnyilvánítás}

A szerzők köszönetet mondanak Kópis Ildikónak és Antal Csabának az adminisztratív és szerkesztési munkákért.

\section{Irodalom}

[1] McLean J. The thromboplastic action of cephalin. Am J Physiol. $1916 ; 41: 250$

[2] Howell WH, Holt E. Two new factors in blood coagulation heparin and proantithrombin. Am J Physiol. 1918; 47: 328-341. 
[3] Campbell HA, Link KP. Studies on the hemorrhagic sweet clover disease IV. The isolation and crystallization of the hemorrhagic agent. J Biol Chem. 1941; 138: 21-33.

[4] Boda Z. Novel strategies in anticoagulant therapy. In: Boda Z. (ed.) Venous thromboembolism - Anticoagulant therapy. [Új stratégiák az antikoaguláns terápiában. In: Boda Z. (szerk.) Vénás tromboembóliák - antikoaguláns terápia.] Medicina Könyvkiadó, Budapest, 2014; pp. 301-325. [Hunarian]

[5] Eriksson BI, Dahl OE, Rosencher N, et al. For the RE-NOVATE Study Group. Dabigatran etexilate versus enoxaparin for prevention of venous thromboembolism after total hip replacement: a randomised, double-blind, non-inferiority trial. Lancet 2007; 370: 949-956.

[6] Eriksson BE, Dahl OE, Huo MH, et al. For the RE-NOVATE II Study Group. Oral dabigatran versus enoxaparin for thromboprophylaxis after primary total hip arthroplasty (RE-NOVATE II). Thromb Haemost. 2011; 105: 721-729.

[7] Eriksson BI, Dahl OE, Rosencher N, et al. For the RE-MODEL Study Group. Oral dabigatran etexilate vs. subcutaneous enoxaparin for the prevention of venous thromboembolism after total knee replacement: the RE-MODEL randomized trial. J Thromb Haemost. 2007; 5: 2178-2185.

[8] Lassen MR, Gallus A, Raskob GE, et al. For the ADVANCE-3 Investigators. Apixaban versus enoxaparin for thromboprophylaxis after hip replacement. N Engl J Med. 2010; 363: 24872498.

[9] Lassen MR, Raskob GE, Gallus A, et al. The ADVANCE-2 investigators. Apixaban versus enoxaparin for thromboprophylaxis after knee replacement (ADVANCE-2): a randomised doubleblind trial. Lancet 2010; 375: 807-815.

[10] Eriksson BI, Borris LC, Friedman RJ, et al. For the RECORDI Study Group. Rivaroxaban versus enoxaparin for thromboprophylaxis after hip arthroplasty. N Engl J Med. 2008; 358: 2765-2775.

[11] Lassen MR, Ageno W, Borris LC, et al. For the RECORD3 Investigators. Rivaroxaban versus enoxaparin for thromboprophylaxis after total knee arthroplasty. N Engl J Med. 2008; 358: 2776-2786.

[12] Chai-Adisaksopha C, Crowther M, Isayama T, et al. The impact of bleeding complications in patients receiving target-specific oral anticoagulants: a systematic review and meta-analysis. Blood 2014; 124: 2450-2458.

[13] Cheung KS, Leung WK. Gastrointestinal bleeding in patients on novel oral anticoagulants: Risk, prevention and management. World J Gastroenterol. 2017; 23: 1954-1963.

[14] Graham DJ, Reichman ME, Wernecke M, et al. Cardiovascular, bleeding, and mortality risks in elderly Medicare patients treated with dabigatran or warfarin for nonvalvular atrial fibrillation. Circulation 2015; 131: 157-164.

[15] Tamayo S, Frank Peacock W, Patel M, et al. Characterizing major bleeding in patients with nonvalvular atrial fibrillation: a pharmacovigilance study of 27467 patients taking rivaroxaban. Clin Cardiol. 2015; 38: 63-68.

[16] Riley TR, Gauthier-Lewis ML, Sanchez CK, et al. Role of agents for reversing the effects of target-specific oral anticoagulants. Am J Health Syst Pharm. 2017; 74: 54-61.

[17] Boda Z. Treatment with inhibitors of new oral direct anticoagulants in patients with severe bleedings or urgent surgical procedures. The new dabigatran antidote: the place of idarucizumab in clinical practice. [Teendők súlyos vérzés vagy sürgős sebészeti beavatkozás esetén direkt orális antikoaguláns gyógyszerrel kezeltekben. Az új dabigatran-antidótum: idarucizumab helye a klinikai gyakorlatban.] Orv Hetil. 2016; 157: 443-450. [Hungarian]

[18] Kearon C, Akl EA, Ornelas J, et al. Antithrombotic therapy for VTE disease: CHEST guideline and expert panel report. Chest 2016; 149: 315-352.
[19] Kirchhof P, Benussi S, Kotecha D, et al. 2016 ESC Guidelines for the management of atrial fibrillation developed in collaboration with EACTS. Eur Heart J. 2016; 37: 2893-2962.

[20] Konstantinides SV, Torbicki A, Agnelli G, et al. 2014 ESC guidelines on the diagnosis and management of acute pulmonary embolism. Eur Heart J. 2014; 35: 3033-3069.

[21] Eikelboom JW, Connolly SJ, Brueckmann M, et al. For the RE-ALIGN investigators. Dabigatran versus warfarin in patients with mechanical heart valves. N Engl J Med. 2013; 369: 12061214.

[22] Beyer-Westendorf J, Marten S, Michalski F. Outcome of NOAC exposure during pregnancy (...and the problem of event reporting...). Blood 2015; 126: 1125.

[23] Weitz JI. Factor Xa and thrombin as targets for new oral anticoagulants. Thromb Res. 2011; 127(Suppl 2): 5S-12S.

[24] Eisert WG, Hauel N, Stangier J, et al. Dabigatran: an oral novel potent reversible nonpeptide inhibitor of thrombin. Arterioscler Thromb Vasc Biol. 2010; 30: 1885-1889.

[25] Stangier, J. Clinical pharmacokinetics and pharmacodynamics of the oral direct thrombin inhibitor dabigatran etexilate. Clin Pharmacokinet. 2008; 47: 285-295.

[26] Driesz L, Barabás E, Bodócs I, et al. The first use of iv. idarucizumab for dabigatran reversal in Hungary. [A dabigatran-antidótum, az intravénás idarucizumab első hazai alkalmazása.] Orv Hetil. 2017; 158: 387-392. [Hungarian]

[27] Perzborn E, Roehrig S, Straub A, et al. Rivaroxaban: a new oral factor Xa inhibitor. Arterioscler Thromb Vasc Biol. 2010; 30: 376-381.

[28] Raghavan N, Frost CE, Yu Z, et al. Apixaban metabolism and pharmacokinetics after oral administration to humans. Drug Metab Dispos. 2009; 37: 74-81.

[29] Ogata K, Mendell-Harary J, Tachibana M, et al. Clinical safety, tolerability, pharmacokinetics, and pharmacodynamics of the novel factor Xa inhibitor edoxaban in healthy volunteers. J Clin Pharmacol. 2010; 50: 743-753.

[30] Thoenes M, Minguet J, Bramlage K, et al. Betrixaban - the next direct factor Xa inhibitor? Expert Rev Hematol. 2016; 9: 11111117.

[31] European Medicines Agency. Xarelto - Summary of product characteristics. Available from: http://www.ema.europa.eu/ docs/en_GB/document_library/EPAR__Product_Information/human/000944/WC500057108.pdf

[32] European Medicines Agency. Pradaxa - Summary of product characteristics. Available from: http://www.ema.europa.eu/ docs/en_GB/document_library/EPAR_-_Summary_for_the_ public/human/000829/WC500041060.pdf

[33] European Medicines Agency. Eliquis - Summary of product characteristics. Available from: http://www.ema.europa.eu/ docs/en_GB/document_library/EPAR_-_Product_Information/human/002148/WC500107728.pdf

[34] European Medicines Agency. Lixiana - Summary of product characteristics. Available from: http://www.ema.europa.eu/ docs/en_GB/document_library/EPAR_-_Summary_for_the_ public/human/002629/WC500189048.pdf

[35] Salmonson T, Dogne JM, Janssen H, et al. Non-vitamin-K oral anticoagulants and laboratory testing: now and in the future. Views from a workshop at the European Medicines Agency (EMA). Eur Heart J Cardiovasc Pharmacother. 2017; 3: 42-47.

[36] Mismetti P, Laporte S. New oral antithrombotics: a need for laboratory monitoring. For. J Thromb Haemost. 2010; 8: 621626.

[37] Ten Cate H. Monitoring new oral anticoagulants, managing thrombosis, or both? Thromb Haemost. 2012; 107: 803-805.

[38] Ten Cate H. New oral anticoagulants: discussion on monitoring and adherence should start now! Thromb J. 2013; $11: 8$.

[39] Douxfils J, Gosselin RC. Laboratory assessment of direct oral anticoagulants. Semin Thromb Hemost. 2017; 43: 277-290. 
[40] Gosselin RC, Adcock DM. The laboratory's 2015 perspective on direct oral anticoagulant testing. J Thromb Haemost. 2016; 14: 886-893.

[41] Samama MM, Guinet C, Le Flem L, et al. Measurement of dabigatran and rivaroxaban in primary prevention of venous thromboembolism in 106 patients, who have undergone major orthopedic surgery: an observational study. J Thromb Thrombolysis 2013; 35: 140-146.

[42] Levy JH, Ageno W, Chan NC, et al. For the Subcommittee on Control of Anticoagulation. When and how to use antidotes for the reversal of direct oral anticoagulants: guidance from the SSC of the ISTH. J Thromb Haemost. 2016; 14: 623-627.

[43] Testa S, Tripodi A, Legnani C, et al. For the START-Laboratory Register. Plasma levels of direct oral anticoagulants in real life patients with atrial fibrillation: Results observed in four anticoagulation clinics. Thromb Res. 2016; 137: 178-183.

[44] Lippi G, Favaloro EJ. Recent guidelines and recommendations for laboratory assessment of the direct oral anticoagulants (DOACs): is there consensus? Clin Chem Lab Med. 2015; 53 : 185-197.

[45] Reiffel JA, Weitz JI, Reilly P, et al. Cardiac Safety Research Consortium presenters and participants. NOAC monitoring, reversal agents, and post-approval safety and effectiveness evaluation: A cardiac safety research consortium think tank. Am Heart J. 2016; 177: 74-86.

[46] Samuelson BT, Cuker A. Measurement and reversal of the direct oral anticoagulants. Blood Rev. 2017; 31: 77-84.

[47] Schmitz EM, Boonen K, van den Heuvel DJ, et al. Determination of dabigatran, rivaroxaban and apixaban by ultra-performance liquid chromatography - tandem mass spectrometry (UPLC-MS/MS) and coagulation assays for therapy monitoring of novel direct oral anticoagulants. J Thromb Haemost. 2014; 12: 1636-1646.

[48] Gous T, Couchman L, Patel JP, et al. Measurement of the direct oral anticoagulants apixaban, dabigatran, edoxaban, and rivaroxaban in human plasma using turbulent flow liquid chromatography with high-resolution mass spectrometry. Ther Drug Monit. 2014; 36: 597-605.

[49] Rohde G. Determination of rivaroxaban - a novel, oral, direct factor Xa inhibitor - in human plasma by high-performance liquid chromatography-tandem mass spectrometry. J Chromatogr B Analyt Technol Biomed Life Sci. 2008; 872: 43-50.

[50] Douxfils J, Mullier F, Robert S, et al. Impact of dabigatran on a large panel of routine or specific coagulation assays. Laboratory recommendations for monitoring of dabigatran etexilate. Thromb Haemost. 2012; 107: 985-997.

[51] Douxfils J, Dogné JM, Mullier F, et al. Comparison of calibrated dilute thrombin time and aPTT tests with LC-MS/MS for the therapeutic monitoring of patients treated with dabigatran etexilate. Thromb Haemost. 2013; 110: 543-549.

[52] Stangier J, Feuring M. Using the HEMOCLOT direct thrombin inhibitor assay to determine plasma concentrations of dabigatran. Blood Coagul Fibrinolysis 2012; 23: 138-143.

[53] Gosselin RC, Dwyre DM, Dager WE. Measuring dabigatran concentrations using a chromogenic ecarin clotting time assay. Ann Pharmacother. 2013; 47: 1635-1640.

[54] Brunetti L, Sanchez-Catanese B, Kagan L, et al. Evaluation of the chromogenic anti-factor IIa assay to assess dabigatran exposure in geriatric patients with atrial fibrillation in an outpatient setting. Thromb J. 2016; 14: 10.

[55] Barrett YC, Wang Z, Frost C, et al. Clinical laboratory measurement of direct factor Xa inhibitors: anti-Xa assay is preferable to prothrombin time assay. Thromb Haemost. 2010; 104: 12631271.

[56] Harenberg J, Marx S, Weiss C, et al. Subcommittee on Control of Anticoagulation of the ISTH. Report of the Subcommittee of Control of Anticoagulation on the determination of the antico- agulant effects of rivaroxaban. J Thromb Haemost. 2012; 10: 1433-1436.

[57] Samama MM, Contant G, Spiro TE, et al. For the Rivaroxaban Anti-Factor Xa Chromogenic Assay Field Trial Laboratories. Evaluation of the anti-factor Xa chromogenic assay for the measurement of rivaroxaban plasma concentrations using calibrators and controls. Thromb Haemost. 2012; 107: 379-387.

[58] Gouin-Thibault I, Flaujac C, Delavenne X, et al. Assessment of apixaban plasma levels by laboratory tests: suitability of three anti-Xa assays. A multicentre French GEHT study. Thromb Haemost. 2014; 111: 240-248.

[59] Douxfils J, Chatelain C, Chatelain B, et al. Impact of apixaban on routine and specific coagulation assays: a practical laboratory guide. Thromb Haemost. 2013; 110: 283-294.

[60] Douxfils J, Chatelain B, Chatelain C, et al. Edoxaban: impact on routine and specific coagulation assays. A practical laboratory guide. Thromb Haemost. 2016; 115: 368-381.

[61] Douxfils J, Tamigniau A, Chatelain B, et al. Comparison of calibrated chromogenic anti-Xa assay and PT tests with LC-MS/MS for the therapeutic monitoring of patients treated with rivaroxaban. Thromb Haemost. 2013; 110: 723-731.

[62] Harenberg J, Du S, Wehling M, et al. Measurement of dabigatran, rivaroxaban and apixaban in samples of plasma, serum and urine, under real life conditions. An international study. Clin Chem Lab Med. 2016; 54: 275-283.

[63] Dias JD, Norem K, Doorneweerd DD, et al. Use of thromboelastography (TEG) for detection of new oral anticoagulants. Arch Pathol Lab Med. 2015; 139: 665-673.

[64] Herrmann R, Thom J, Wood A, et al. Thrombin generation using the calibrated automated thrombinoscope to assess reversibility of dabigatran and rivaroxaban. Thromb Haemost. 2014; 111: 989-995.

[65] Adelmann D, Wiegele M, Wohlgemuth RK, et al. Measuring the activity of apixaban and rivaroxaban with rotational thrombelastometry. Thromb Res. 2014; 134: 918-923.

[66] Chojnowski K, Górski T, Robak M, et al. Effects of rivaroxaban therapy on ROTEM coagulation parameters in patients with venous thromboembolism. Adv Clin Exp Med. 2015; 24: 9951000.

[67] Helin TA, Lemponen M, Hjemdahl P, et al. From laboratory to clinical practice: dabigatran effects on thrombin generation and coagulation in patient samples. Thromb Res. 2015; 136: 154160 .

[68] Adcock DM, Gosselin R. Direct oral anticoagulants (DOACs) in the laboratory: 2015 Review. Thromb Res. 2015; 136: 7-12.

[69] Kitchen S, Gray E, Mackie I, et al. On behalf of the BCSH committee. Measurement of non-coumarin anticoagulants and their effects on tests of haemostasis: Guidance from the British Committee for Standards in Haematology. Br J Haematol. 2014; 166: 830-841.

[70] Hawes EM, Deal AM, Funk-Adcock D, et al. Performance of coagulation tests in patients on therapeutic doses of dabigatran: a cross sectional pharmacodynamics study based on peak and trough levels. J Thromb Haemost. 2013; 11: 1493-1502.

[71] Van Ryn J, Stangier J, Haertter S, et al. Dabigatran etexilate - a novel reversible oral direct thrombin inhibitor: Interpretation of coagulation assays and reversal of anticoagulant activity. Thromb Haemost. 2010; 103: 1116-1127.

[72] Dager WE, Gosselin RC, Kitchen S, et al. Dabigatran effects on the international normalized ratio, activated partial thromboplastin time, thrombin time, and fibrinogen: a multicenter, in vitro study. Ann Pharmacother. 2012; 46: 1627-1636.

[73] Lim MS, Chapman K, Swanepoel P, et al. Sensitivity of routine coagulation assays to direct oral anticoagulants: patient samples versus commercial drug-specific calibrators. Pathology 2016; 48 : 712-719. 
[74] Van Veen JJ, Smith J, Kitchen S, et al. Normal prothrombin time in the presence of therapeutic levels of rivaroxaban. Br J Haematol. 2013 ; 160: 859-861.

[75] Rodgers R, Bagot CN, Lawrence C, et al. Correlating prothrombin time with plasma rivaroxaban level. Br J Haematol. 2013; 163: 685-687.

[76] Harenberg J, Marx S, Krämer R, et al. Determination of an international sensitivity index of thromboplastin reagents using a WHO thromboplastin as calibrator for plasma spiked with rivaroxaban. Blood Coagul Fibrinolysis 2011; 22: 637-641.

[77] Tripodi A, Chantarangkul V, Guinet C, et al. The International Normalized Ratio calibrated for rivaroxaban has the potential to normalize prothrombin time results for rivaroxaban-treated patients: results of an in vitro study. J Thromb Haemost. 2011; 9: 226-228.

[78] Francart S, Hawes EM, Deal A, et al. Performance of coagulation tests in patients on therapeutic doses of rivaroxaban. A crosssectional pharmacodynamic study based on peak and trough plasma levels. Thromb Haemost. 2014; 111: 1133-1140.

[79] Eby C. Novel anticoagulants and laboratory testing. Int J Lab Hematol. 2013; 35: 262-268.
[80] Bonar R, Favaloro EJ, Mohammed S, et al. The effect of dabigatran on haemostasis tests: a comprehensive assessment using in vitro and ex vivo samples. Pathology 2015; 47: 355-364.

[81] Mani H, Hesse C, Stratmann G, et al. Ex vivo effects of low-dose rivaroxaban on specific coagulation assays and coagulation factor activities in patients under real life conditions. Thromb Haemost. 2013; 109: 127-136.

[82] Adcock DM, Gosselin R, Kitchen S, et al. The effect of dabigatran on select specialty coagulation assays. Am J Clin Pathol. 2013; 139: 102-109.

[83] Ratzinger F, Lang M, Belik S, et al. Lupus-anticoagulant testing at NOAC trough levels. Thromb Haemost. 2016; 116: 235240.

[84] Favaloro EJ, Lippi G. Laboratory testing in the era of direct or non-vitamin $\mathrm{K}$ antagonist oral anticoagulants: A practical guide to measuring their activity and avoiding diagnostic errors. Semin Thromb Haemost. 2015; 41: 208-227.

(Kappelmayer János dr., Debrecen, Nagyerdei krt. 98., 4032 e-mail: kappelmayer@med.unideb.hu)

\section{NOTA}

\section{Új fejlesztés az egészségügyben dolgozók, tanulók részére!}

A magyar nyelvứ szakirodalmi keresőszolgáltatás

\section{Mi a NOTA? \\ Napivizit Orvosi Tudástár Alkalmazás}

Mit tud a NOTA portál?

Megkönnyíti a magyar nyelvű szakirodalmi források keresését.

Eszköztöl függetlenül, akár okostelefonról, a betegágy mellett állva is használható.

\section{Miben kereshet a NOTA-val?}

Az Akadémiai Kiadó folyóirataiban: Orvosi Hetilap, Magyar Sebészet, Mentálhigiéné és Pszichoszomatika.

\section{Más kiadók magyar nyelvü} szakfolyóirataiban: pl. Lege Artis Medicinae, Hypertonia és Nephrologia, Ideggyógyászati Szemle.

A hatályos szakmai irányelvekben.

Magyar nyelvű kérdésekre adott angol nyelvű találatokban, a PubMeden.

\section{nota.hu}

Amennyiben további információra lenne szüksége, keressen minket elérhetőségeinken:

journals@akademiai.hu /hirdetes@akademiai.hu

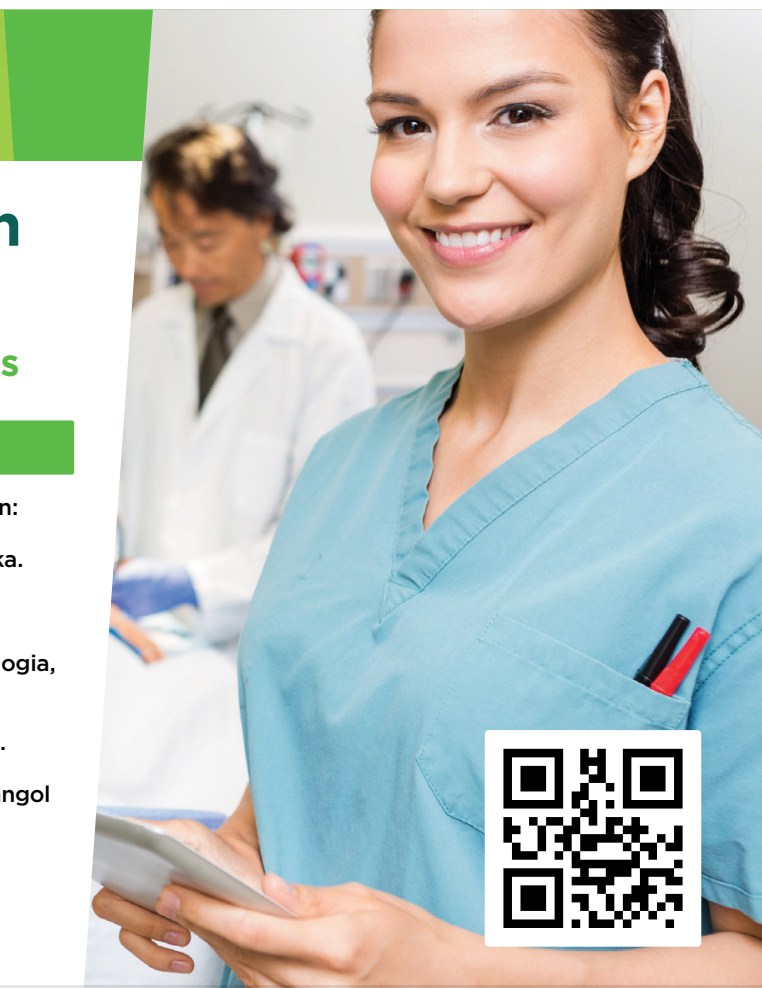

\section{Akadémiai Kiadó}

A Wolters Kluwer Csoport tagja

1117 Budapest, Prielle Kornélia u. 21-35. / Telefon: (1) 464-8246 www.akademiai.hu / www.akademiai.com

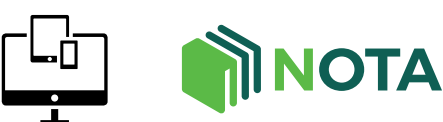

AKADÉMIAI KIADÓ 